bioRxiv preprint doi: https://doi org/10 1101/682526; this version posted June 26,2019 . The copyright holder for this preprint (which was

not certified by peer review) is the author/funder, who has granted bioRxiv a license to display the preprint in perpetuity. It is made available under aCC-BY-NC-ND 4.0 International license.

\title{
Nuclear lipidome is altered in amyotrophic lateral sclerosis: a preliminary study
}

Omar Ramírez-Nuñez ${ }^{\mathrm{a}, 1}$, Mariona Jové ${ }^{\mathrm{a}, 1}$, Pascual Torres ${ }^{\mathrm{a} 1}$, Joaquim Sol ${ }^{\mathrm{a}}$, Laia Fontdevila ${ }^{\text {a }}$, Ricardo Romero-

Guevara $^{\mathrm{a}}$, Victòria Ayala ${ }^{\mathrm{a}}$, Chiara Rossi ${ }^{\mathrm{a}}$, Jordi Boada ${ }^{\mathrm{a}}$, Mònica Povedano ${ }^{\mathrm{b}}$, Pol Andrés-Benito ${ }^{\mathrm{c}, \mathrm{d}}$, Isidro Ferrer c,d , Reinald Pamplona ${ }^{\mathrm{a}}$, Manuel Portero-Otin ${ }^{\mathrm{a}, 2}$

OR-N:omar.ramirez78@gmail.com; MJ:mariona.jove@mex.udl.cat; PT:pascual.torres@mex.udl.cat;

JS:solcullere@gmail.com;LF:laia_fontdevila@hotmail.com; RR-G:rromeroguevara@gmail.com;

VA:victoria.ayala@mex.udl.cat;CR: clara70289@mex.udl.cat; JB:Jordi.boada@mex.udl.cat;RP:

Reinald.pamplona@mex.udl.cat

${ }^{a}$ Department of Experimental Medicine, School of Medicine, IRBLleida-UdL, Avda Rovira Roure 8025196 ,

Lleida, Spain

MP: 30058mpp@gmail.com

${ }^{b}$ Neurology Service, Hospital Universitari de Bellvitge, L'Hospitalet de Llobregat, c/La Feixa Llarga, S/N

08908 Hospitalet de Llobregat, Barcelona, Spain

PA-B:pol.andres.benito@gmail.com; IF:8082ifa@gmail.com

${ }^{c}$ Departament of Pathology and Experimental Therapeutics, Universitat de Barcelona; Hospital Universitari de Bellvitge, IDIBELL, Hospitalet de Llobregat;

${ }^{\mathrm{d}}$ CIBERNED (Centro de Investigación Biomédica en Red de Enfermedades Neurodegenerativas), Instituto

Carlos III, c/La Feixa Llarga sn, 08908 Hospitalet de Llobregat, Barcelona, Spain

${ }^{1}$ These authors contributed equally to this work

${ }^{2}$ To whom correspondence should be addressed at IRBLleida-UdL, Edifici Biomedicina I, Avda Rovira Roure 80 E25196 Lleida, Spain. Phone +34973702408; Fax: +34973702426; e-mail: manuel.portero@mex.udl.cat

\begin{abstract}
In this pilot study, we show that nuclei in spinal cord from ALS patients exhibit a differential lipidomic signature. Among the differential lipid species we could annotate 41 potential identities. These comprise membrane-bound lipids such as phosphatidylethanolamines -including plasmalogens- and phosphatidylcholines but also other lipid classes such as glycosphingolipids, diacylglycerols, and triacylglycerides (potentially present
\end{abstract}


bioRxiv preprint doi: https://doi.org/10.1101/682526; this version posted June 26, 2019. The copyright holder for this preprint (which was

not certified by peer review) is the author/funder, who has granted bioRxiv a license to display the preprint in perpetuity. It is made available under aCC-BY-NC-ND 4.0 International license.

nuclear lipid droplets). These results were orthogonally validated by showing loss of alkyldihydroxyacetonephosphate synthase (AGPS), a key peroxisomal enzyme in plasmalogen synthesis, both in ALS necropsy samples, in human motor neurons derived from iPSC from ALS patients and in hSOD-G93A transgenic mice. Further, diacylglycerol content changes were associated to ALS-linked variations in relatedenzymes, such as phospholipase C BI (PLCßI), the source of nuclear diacylglycerol, and protein kinase CßII (PKCßII), whose function partially depends on nuclei concentration of diacylglycerol. These results point out for not only a role of nuclear membrane lipids but also to lipids present in the nucleoplasm, suggesting an undisclosed role for this part of the subcellular lipidome in ALS pathophysiology.

\section{Keywords}

Motor neuron; lipidomic; nuclear envelope; polyunsaturated fatty acids; subcellular lipidomics; phospholipase C ßI; protein kinase CßII; alkyldihydroxyacetonephosphate synthase

\section{INTRODUCTION}

Amyotrophic lateral sclerosis (ALS) is a devastating neurodegenerative disease, where patients exhibit a loss in motor neuron number. This cell demise has been associated to a number of cellular events common to other agerelated neurodegenerative conditions. These include the accumulation of modified proteins, such as Tar-DNA binding of $43 \mathrm{kDa}$ (TDP-43) and ERK, in non-physiological subcellular locations [1]. Interestingly, these proteins play essential roles in nucleus, so their presence out of nucleus might be a consequence of an impairment in normal nucleocytosolic traffic. Indeed, it is known that this physiological trait is affected in ALS[2]. Nucleocytosolic transport depends on a series of proteins such as Ran-GTPases as well as the nuclear pores function. Of note, these nuclear pores are embedded into the nuclear envelope lipid bilayers. Further, recent data demonstrate alterations in nuclear membrane in ALS models [3]

Lipids are key players in cellular physiology. Lipid composition is an essential feature of neural tissue. Recent data from our group and others have revealed that in ALS an extensive array of changes involving tissue lipidome is present. Indeed, in experimental models of ALS, dietary changes in lipid composition induce changes in phenotype of this neurodegenerative condition. Furthermore, epidemiological data demonstrate that the dietary intake of selected lipids (such as those belonging to $n-3$ family) is a relevant factor in predicting the incidence of this condition[4]. 
bioRxiv preprint doi: https://doi.org/10.1101/682526; this version posted June 26, 2019. The copyright holder for this preprint (which was

not certified by peer review) is the author/funder, who has granted bioRxiv a license to display the preprint in perpetuity. It is made available under aCC-BY-NC-ND 4.0 International license.

To the date, the lipidome of nuclear envelopes has been focus of relative attention in some conditions [5]. However, whether it is affected in ALS is currently unknown. To shed light into this question, we designed a pilot study to analyze samples from spinal cord of ALS patients, and age and gender matched individuals, to explore if ALS is associated to changes in nuclear lipidome(s). This has been achieved after nuclei enrichment from frozen tissues after necropsy and subsequent lipid analyses by liquid chromatography coupled to time-offlight mass spectrometry. The results reveal an important change not only in typical membrane lipids but also affecting signaling molecules. The suggested pathogenic pathways have been validated independently by evaluating the levels and distribution of key proteins related with differential lipids, both in human samples and in a transgenic mice model overexpressing an ALS-related gene.

\section{METHODS}

\section{Human and mice neuronal tissues}

All human samples were obtained from the Institute of Neuropathology and HUB-ICO-IDIBELL Brain Bank following the guidelines of the local ethics committees. Extensive pathological studies were done for ALS diagnosis as previously described[6]. Samples lumbar spinal cord were from 2 males and 2 females aged between 57 and 79 years affected with typical neurological and neuropathological characteristics of sporadic ALS. The post-mortem delay between death and tissue processing was between 3 and 16h. Age- and gendermatched controls with no clinical evidences of neurological disease and with a normal neuropathological study were processed in parallel (see Table 1).

We also employed lumbar spinal cord samples from male mice (150 d, $n=5)$ from the strain B6SJL-Tg (SOD1G93A)1Gur/J ( from now on G93A) purchased at The Jackson Laboratories (JAX catalogue stock number 002726, Bar Harbor, MN, USA) and maintained in the B6SJL background, by male founder crossing with B6SJLF1/J. As controls we employed non-transgenic littermates. Mice care and housing have been previously described [7]. Animals, after being fasted overnight, were anaesthetized with $2.5 \%$ isoflurane in air and finally sacrificed. Spinal cords were rapidly excised, frozen in liquid $\mathrm{N}_{2}$ and stored at $-80^{\circ} \mathrm{C}$ until further analyses. 
bioRxiv preprint doi: https://doi.org/10.1101/682526; this version posted June 26, 2019. The copyright holder for this preprint (which was

not certified by peer review) is the author/funder, who has granted bioRxiv a license to display the preprint in perpetuity. It is made available under aCC-BY-NC-ND 4.0 International license.

For western-blot, samples were homogenized on ice in a buffer containing $180 \mathrm{mM} \mathrm{KCl,} 5 \mathrm{mM}$ MOPS, $2 \mathrm{mM}$ EDTA, 1mM diethylenetriaminepentaacetic acid, and $1 \mu \mathrm{M}$ of freshly prepared butylated hydroxyl toluene at pH 7.3 using a homogenizer device (T10 basic UltraTurraX, IKA, Staufen, Germany). Protein concentrations were measured by the Bradford method. For immunohistochemistry, animals after sacrifice were exanguinated by perfusion, firstly with saline solution $\left(4^{\circ} \mathrm{C}\right)$ and thereafter with ice cold $0.4 \%$ paraformaldeyde (SigmaAldrich, Sant Louis, MO, USA) solution (freshly prepared with $\mathrm{pH} 7.4$ phosphate buffer). All experimental procedures were approved by the Institutional Animal Care Committee of IRBLleida and were conformed to the Directive 2010/63/EU of the European Parliament.

\section{Human Induced pluripotent stem (hIPS)cell-derived motor neurons}

hiPS were obtained from NINDS Human Genetics DNA and Cell line Repository at Coriell Institute (Camden, NJ, USA \#ND35663 -with a mutation in FUS-, \#ND42765 -with a C9ORF72 expansion-, and \#ND41865 control cell line-) and grown in standard human embryonic stem (ES) cells media supplemented with $6 \mathrm{ng} / \mathrm{ml}$ basic Fibroblast Growth Factor (bFGF) on inactivated mouse embryonic fibroblast (MEFs) (Sigma) as feeder cells. Differentiation towards motor neurons was carried by a modification of Du et al protocol[8]. Briefly, undifferentiated hiPSC cultures were digested with Accutase solution (Sigma-Aldrich) for 5 min, seed for 40

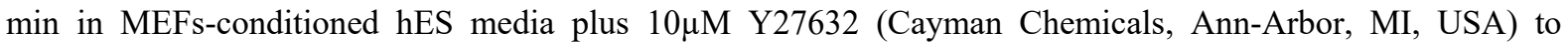
remove as many fibroblasts as possible, then the cell suspension was transferred into Geltrex $\mathbb{R}(\mathrm{Thermo}$ Scientific)-coated tissue culture dishes for $24-48 \mathrm{hrs}$ until stem colonies were visible. Media was then changed to neuroepithelial media (NEPM) for 6 days, and then replaced sequentially to motorneuron progenitor (MNPs) media 1 st and 2nd, 6 days in each of them. At this point, progenitors were either expanded on MNPs 2nd or further differentiated into neurospheres and motor neurons using motor neuron induction media and motor neuron maturation media respectively. Importantly, for neurosphere formation non-tissue culture dishes without coating were used. Both neuroepithelial and MNPs were split into new Geltrex $®$-coated dishes when 70-100\% confluent and seed at 50-75 000 cells $/ \mathrm{cm}^{2}$ and always using Y27632 $10 \mu \mathrm{M}$ during the $1 \mathrm{st} 24$ hrs. Media was changed every other day.

After 6 days in motor neuron induction media, neurospheres were collected in a15 ml centrifuge tube, spin down $3.5 \mathrm{~min}$ at 0.1 ref, supernatant discarded and spheres digested for 5-7 min in Accumax solution (Sigma). With the help of a pipette, cells clusters were disaggregated until an homegenous single cell suspension was obtained. Cells were then washed with DMEM/F12 (Thermo Scientific) and resuspended in motor neuron 
bioRxiv preprint doi: https://doi.org/10.1101/682526; this version posted June 26, 2019. The copyright holder for this preprint (which was

not certified by peer review) is the author/funder, who has granted bioRxiv a license to display the preprint in perpetuity. It is made available under aCC-BY-NC-ND 4.0 International license.

maturation media for seeding, media was supplemented with Y27632, Laminin $(2.5 \mu \mathrm{g}$ per 1ml of media, Thermo-Fisher) and 0.1 $\mu \mathrm{M}$ Compound-E (Stem Cell Technologies, Grenoble, France) during the first 3 days after plating in Poly-L-Lysine (Sigma) coated dishes, media change was done every 72 hrs. Seeding density was maintained at 50-100 000 cells $/ \mathrm{cm}^{2}$. The different media composition appears in the Table 2.

\section{Nuclear enrichment}

Nuclei were extracted from portions of the human spinal cord according to a variation of the Blobber and Potter protocol [9]. We started from about $0.270 \mathrm{~g}$ of frozen tissue, which was allowed to thaw at $4{ }^{\circ} \mathrm{C}$. All subsequent steps, unless noted otherwise, were performed at this temperature. Once thawed, samples were cut into very small pieces with a scalpel and transferred to a $2 \mathrm{~mL}$ eppendorff, where the tissue was homogenized in two volumes $(\mathrm{w} / \mathrm{v})$ of $0.25 \mathrm{M}$ sucrose in cold TKM (0.05 M Tris, $0.025 \mathrm{M} \mathrm{KCl}$. MgCl2 $0.005 \mathrm{M})$ and commercial protease and phosphatase inhibitors (78440, Thermo Scientific). The homogenization was first performed with a Polytron ${ }^{\circledR}$ mechanical homogenizer with a plastic plunger with approximately 20-40 strokes. The homogenate was then passed to a Dounce-type homogenizer with a glass tight plunger (20-40 strokes). At the end of this step, the homogenate $(540 \mu \mathrm{L})$ was transferred to an ultracentrifuge tube (Beckman Coulter, 344057), and 1080 $\mu \mathrm{L}$ of $2.3 \mathrm{M}$ sucrose in TKM were added, with the contents of the tube were carefully mixed by inversion. A pipette was then introduced to the bottom of the centrifuge tube and $540 \mu \mathrm{L}$ of $2.3 \mathrm{M}$ sucrose in TKM were carefully added, ensuring that well-defined phases of sucrose were formed, where the homogenate remained at the top. The ultracentrifuge tubes were centrifuged at $124000 \mathrm{x}$ g at $4{ }^{\circ} \mathrm{C}$ for 30 minutes in Optima L-100XP ultracentrifuge (Beckman Coulter, SW 55 Ti rotor). The resulting pellet was suspended in $50 \mu \mathrm{L}$ of TKM with protease inhibitors and commercial phosphatases (78440, Thermo Fisher Scientific). The presence of nuclei was confirmed by fluorescence microscopy, after staining with DAPI at $1 \mu \mathrm{g} / \mathrm{mL}$. For comparison of nuclear enrichment, mitochondrial enriched fractions were isolated as indicated in Mitochondria Isolation Kit for Tissue (Ab110168, Abcam).

\section{Lipidomics of isolated nuclei}

The lipids of the isolated spinal cord nuclei extracted post mortem of ALS patients and controls were extracted using methyl-tert-butyl-ether with the help of a sonicator, after adding deuterated internal standards representing major lipid classes[10]. The analysis was performed using a liquid chromatograph (Agilent 1290 UPLC) coupled to a mass spectrometer (Agilent 6520 ESIQTOF-MS) that allows the characterization of lipids and 
bioRxiv preprint doi: https://doi.org/10.1101/682526; this version posted June 26, 2019. The copyright holder for this preprint (which was

not certified by peer review) is the author/funder, who has granted bioRxiv a license to display the preprint in perpetuity. It is made available under aCC-BY-NC-ND 4.0 International license.

metabolites based in the exact mass $(<10 \mathrm{ppm})$, isotopic spectrum and in retention times of internal standards marked isotopically and representative of the major lipid classes. Lipid species were separated through reverse phase chromatography (Waters Acquity HSS T3 $\times 0.1 \mathrm{~mm} \times 100 \mathrm{~mm}$ at $55^{\circ} \mathrm{C}$ ), in suitable gradients and previously described [10]. The eluate was monitored in the Q-TOF system by electroespray in positive and negative ionization mode, collecting data in a range of m/z from 100 to 3000 , with ionization source at $120^{\circ} \mathrm{C}$ and using $\mathrm{N} 2$ as a solvation gas at $250{ }^{\circ} \mathrm{C}(800 \mathrm{~L} / \mathrm{h})$. The exact mass adjustment is performed by joint infusion in reference spray of purine and HP9982, with exact masses with errors less than 0.5 ppm. Tandem mass spectrometry was performed as described[10].

After the extraction of the molecular characteristics, the analysis of the results was performed using the Mass Profiler software (Agilent, version for mass spectrometry). All samples were coded and analyzed in double blind mode. After the data collection, they were decoded and the relevant statistical analyses, both univariate and multivariate, by the R package OrbisMet (available in http://hdl.handle.net/10609/65305 )

\section{Microscopy of isolated nuclei.}

The isolated nuclei were fixed in 4\% paraformaldehyde $(\mathrm{w} / \mathrm{v})$ in PBS at a 1/3 (nuclei solution/fixation solution) at room temperature for 15 minutes. Subsequently, $20 \mu \mathrm{L}$ of the mixture were placed on a round coverslip (12 $\mathrm{mm})$, which was subsequently centrifuged $(100 \mathrm{xG}, 3 \mathrm{~min})$. At the end of the time, coverslips were taken with fine forceps and placed on a Parafilm ${ }^{\circledR}$-covered support. The nuclei were incubated in a permeabilization and blocking solution (Triton X-100 0.1\%, normal goat serum 10\% in PBS) for 30 minutes at room temperature. Then, three gentle washes were carefully made with PBS. Coverslips were incubated at $4^{\circ} \mathrm{C}$ overnight (in a humid chamber) with the appropriate primary antibodies at the indicated final concentrations, dissolved in 1/10 (v/v) of blocking solution in PBS. After this incubation period, three washes were made with PBS and the samples were incubated with the appropriate secondary antibody dissolved in PBS and $1 \mu \mathrm{g} / \mathrm{mL}$ DAPI for nuclear staining, at $4{ }^{\circ} \mathrm{C}$ for 1 hour. Finally, 3 washes of 5 minutes each were made with PBS and the nuclei were mounted on slides with Fluoromount-G solution (00-4959-52, Thermo Fisher Scientific) and allowed to dry at room temperature. Nile Red at $10 \mu \mathrm{g} / \mathrm{mL}$ in PBS was used to evaluate the presence of lipid droplets, by incubating coverslips containing fixed nuclei at $37^{\circ} \mathrm{C}$ for $30 \mathrm{~min}$.

\section{Western Blot analysis}


bioRxiv preprint doi: https://doi.org/10.1101/682526; this version posted June 26, 2019. The copyright holder for this preprint (which was

not certified by peer review) is the author/funder, who has granted bioRxiv a license to display the preprint in perpetuity. It is made available under aCC-BY-NC-ND 4.0 International license.

In case of human samples, protein from different fractions (total lysates, mitochondrial and nuclei enriched fractions) was extracted using radioimmunoprecipitation buffer with Halt Protease Inhibitor Cocktail (1X) (1861278, Thermo Fisher Scientific). After sonication, protein quantification was performed with Bradford assay. Both for human and mice samples, $15 \mu \mathrm{g}$ of protein were loaded onto a $12 \%$ acrylamide SDS-PAGE gel. Membranes were blocked with I-Block (T2015, Thermo Fisher Scientific) for 1 hour and incubated overnight with the antibodies and conditions listed in Table 2. After primary antibody incubation, membranes were washed 3 times with TBS-T $0.05 \%$ and incubated with secondary antibody for $1 \mathrm{~h}$. Immobilon ${ }^{\mathrm{TM}}$ Western Chemiluminiscent HRP Substrate (Merck Millipore, WBKLS0500, Billerica, MA, USA) was used for immunodetection. Membranes were stained with Coomassie Brilliant Blue G (27815, Sigma-Aldrich) for normalization. Specific bands were quantified with ImageLab v5.2.1 (Bio-Rad). Omission of primary antibody resulted in complete loss of signal.

\section{Immunofluorescence.}

Immunofluorescence was performed essentially as previously described [1]. Briefly, after tissue collection (lumbar spinal cord) in mice, samples were immersed for $24 \mathrm{~h}$ in paraformaldehyde solution to assure preservation. Samples were thereafter immersed in 30\% sucrose, (made in pH 7.4 phosphate buffer) for $48 \mathrm{~h}$ to achieve cryopreservation. Tissue was encased in a cubic recipient (Peel-A-Way Disposable Embeding MoldsS-22, Polysciences Inc., Warrington, PA, USA), labelled and embedded in tissue freezing medium (Triangle Biomedical Sciences Inc., Newcastle, UK) for easy cutting and better preservation and finally frozen $\left(-80^{\circ} \mathrm{C}\right)$. Sixteen $\mu \mathrm{m}$ wide sections of lumbar spinal cord were cut and carefully seeded along gelatin-coated slide. Selected sections were permeabilized with $0.1 \%$ Triton X-100 in PBS for $30 \mathrm{~min}$ at room temperature. Blocking of sections was performed with 5\% normal goat serum in $0.1 \%$ Triton X-100 PBS at room temperature for $1 \mathrm{~h}$. In the case of human MNs, cells (grown in glass coverslips) were washed with PBS and then fixed with $3.7 \%$ paraformaldehyde for $10 \mathrm{~min}$ at room temperature. Cells were rinsed with PBS, permeabilised with $0.1 \%$ Triton X-100 in PBS for 30 min and subsequently blocked with 5\% fetal horse serum at room temperature for 2 hours.

For immunofluorescence, slides (mouse spinal cord sections) or coverslips (human MNs) were incubated at 4 ${ }^{\circ} \mathrm{C}$ overnight with the primary antibodies indicated on table 3 . Next day, slides and coverslips were washed with 
bioRxiv preprint doi: https://doi.org/10.1101/682526; this version posted June 26, 2019. The copyright holder for this preprint (which was

not certified by peer review) is the author/funder, who has granted bioRxiv a license to display the preprint in perpetuity. It is made available under aCC-BY-NC-ND 4.0 International license.

PBS three times for $5 \mathrm{~min}$ at room temperature. Then, they were incubated at room temperature for $1 \mathrm{~h}$ in darkness with corresponding secondary antibodies. Sections and cells were finally counterstained with 4,6diamidino-2-phenylindole dihydrochloride (DAPI, $1 \mathrm{ug} / \mathrm{ml}$ ) in PBS at room temperature for $10 \mathrm{~min}$ and, after three washes with PBS, mounted on slides with Vectashield (Vector Laboratories, Burlingame, CA, USA). In selected sections and coverslips, primary antibody was omitted to assure labelling specificity. Mounted slices were examined under a Fluoview 500 Olympus confocal laser scanning microscope (Olympus, Hamburg, Germany). For quantification tissue immunoreactivity images were analyzed with the Image $\mathrm{J}$ software (http://rsbweb.nih.gov/ij/) and human MNs images were evaluated using an ad-hoc designed Cell Profiler pipeline (http://cellprofiler.org), available in supplemental materials.

\section{Statistical analyses}

All statistics were performed using the Prism software (GraphPad Software, San Diego, CA, USA). Differences between groups were analyzed by the Student's t tests or ANOVA after normality of variable distribution was ensured by Kolmogorov-Smirnov test. The 0.05 level was selected as the point of minimal statistical significance in every comparison

\section{RESULTS}

The described method (Figure 1a) leads to a fraction enriched in nuclei, derived from frozen tissues. The nuclei present in this fraction exhibit a preserved nuclear morphology (DAPI positivity with high nucleoporin content -Figure 1b). Further, a high content of nuclear specific proteins was demonstrated by western blot analyses (Figure 1C). The potential presence of membrane containing organelles, such as mitochondria, was excluded, based on the content of mitochondrial membrane markers such as porin or mitofusin (Figure 1c).

Lipidomic analyses disclosed significant differences between nuclei from ALS and age-matched healthy controls. Thus, principal component analyses (PCA) explained more than $50 \%$ of total variances (either in negative or in positively ionized lipids) of present samples in a model of three components (Figure 2a). Further, partial-least square models offered an accuracy in predicting the groups $c a 100 \%$, with more than $60 \%$ of total variance in lipidomic profiles being explained in three major components, demonstrating the robustness of the model (Figure 2b). As shown by hierarchical clustering analyses (Figure 2c), marked differences were present among the lipidomic profiles of the resulting nuclei enriched fractions. 
bioRxiv preprint doi: https://doi.org/10.1101/682526; this version posted June 26, 2019. The copyright holder for this preprint (which was

not certified by peer review) is the author/funder, who has granted bioRxiv a license to display the preprint in perpetuity. It is made available under aCC-BY-NC-ND 4.0 International license.

Univariate analyses ( $\mathrm{T}$ test) demonstrated the presence of 151 differential molecules (99 in positive ionization and 52 in negative ionization, Supplemental table 1, p values between 9.46x10E-15 and 0.05). Among these, putative identities, based on isotope distribution pattern and retention time identity with internal standards representative of lipid major families, were found for 41 different molecules (25 upregulated in ALS samples; Table 3), with $\mathrm{p}$ values ranging from $5.35 \times 10 \mathrm{E}-5$ to 0.05 . Potential identities (comprising isobaric molecules) included 8 ceramides, 9 diacilglycerol, 8 phosphatidylcholines, 15 phosphatidylethanolamines, 9 phosphatidic acid, 7 phosphatidylserines, 2 phosphoinositides and 11 triacylglycerides.

After tandem mass spectrometry, we were able to confirm the identity of diacylglycerol molecules (DAG). One of the mediators of DAG is PKCßII. In line with altered levels of DAG, decreased levels of PKCBII were measured in both spinal cord lysates from ALS patients (Figure 3a) and lysates from G93A mice (Figure 3b), in comparison to adequate controls. Further, as DAG can be the result of the activation of an specific PLC isoform (ßI), we measured its levels in the same samples. Though immunoreactivity was near to marginal in human spinal cord lysates, clear decreases could be also measured in G93A spinal cord lysates (Figure 3c and 3d).

Similarly, as differential lipids also comprised several plasmalogens, we explored the potential changes of one of the rate-limiting enzymes for plasmalogen synthesis, AGPS [11], a peroxisomal enzyme. The results indicate that ALS could influence AGPS levels in spinal cord. Thus, western-blot analyses (Figure 4a) demonstrate significantly decreased levels in spinal cords of G93A mice in comparison with non-Tg animals. In contrast, in lysates from human samples, we were not able to reproduce this fact (Figure 4b). Noteworthy, in human motor neurons derived from IPs, the anti-AGPS immunroeactivity in two cell lines from known ALS-causing mutations (FUS and C9orf72 expansions) was lower than that from control cell line (Figure 4c). Further, there was a significant correlation between nuclear perimeter and AGPS levels in both control and C9orf72 cell lines, but not in FUS mutants. Confirming these data, in mice spinal cord, this protein was preferentially present in motor neurons, whose levels were severely decreased in 150 days old G93A mice (Figure 4d).

Furthermore, some of the potential identities of the differential lipids are alkyl-phospholipids, whose synthesis is also dependent on peroxisome function. To evaluate whether changes in AGPS and in alkyl-phospholipids are due to a potentially specific peroxisomal defect, we evaluated PMP70 distribution in G93A mice. Results 
bioRxiv preprint doi: https://doi.org/10.1101/682526; this version posted June 26, 2019. The copyright holder for this preprint (which was

not certified by peer review) is the author/funder, who has granted bioRxiv a license to display the preprint in perpetuity. It is made available under aCC-BY-NC-ND 4.0 International license.

(Figure 5a) show that despite PMP70 enriched vesicles were present in many remaining motor neurons in G93A mice spinal cord, no general increases were evident by western-blot. Since we also detected differential phospholipid compositions in nuclear isolates, we evaluated SCP-2 expression. SCP-2 is a peroxisomal/ER resident protein implicated in phospholipid synthesis[12], particularly phosphatydilethanolamine and phosphatidylserine. In line with differential phospholipids found in nuclei isolated from ALS samples, we found a marked rearrangement of SCP-2 immunoreactivity in G93A mice. As shown in figure 5c, in control mice, SCP-2 expression was preferentially found around the nuclei, this was not the case in many motor neurons from G93A mice, with redistribution on this immunoreactivity towards vesicles with no perinuclear enrichment. Further, levels of SCP-2 were significantly increased, as shown by western-blot analyses.

Finally, across the differential lipids in enriched nuclear fractions we detected molecules compatible with triacylglycerides. As these are usually found in lipid droplets[13], we explored if lipid droplets could be found along the purified nuclei. As shown in figure 6, Nile Red stained vesicles could be found associated with the nuclei and even inside.

\section{DISCUSSION}

The analysis of the lipidomic profile of the isolated nuclei of post tissue mortem of ALS patients and controls demonstrate a differential profile between control group and the pathological group. To the best of our knowledge, this is the first report indicating a difference in this subcellular parameter in this devastating neurodegenerative disease. There is not a large number of references on cellular membrane alterations in ALS and their models, although in previous studies of our group [6,7], demonstrate severe changes in tissue lipidomes in ALS and ALS models, depending on disease stage and anatomical location.On the other hand, it should be remembered that one of the forms of familial ALS (subtype 8), is due to a mutation in the VAP-B protein, involved in intracellular membrane trafficking [14]. Thus, it can be expected that the composition of the intracellular membranes is a relevant factor in pathophysiology of ALS.

Specifically about the nuclear envelope, it has been recently described that failures in nucleocytosolic transport, depending in part from importins, are present in ALS [15]. The interaction between the lipids of the nuclear membranes and the nucleoporins -integral components of nuclear pore- as well as their contribution to cellular homeostasis is a field largely unknown. To perform their function, nucleoporins need to be anchored adequately 
bioRxiv preprint doi: https://doi.org/10.1101/682526; this version posted June 26, 2019. The copyright holder for this preprint (which was

not certified by peer review) is the author/funder, who has granted bioRxiv a license to display the preprint in perpetuity. It is made available under aCC-BY-NC-ND 4.0 International license.

at the fusion points between the nuclear membranes of external and internal nuclear envelope[16]. There are highly specialized regions of specific nucleoporins (such as Pom121, GP201) structurally dependent on phospholipids where these proteins are anchored into $[17,18]$. In addition to these transmembrane proteins, other proteins, such as members of the NUP107-160 complex contain domains that interact with the nuclear membranes[19,20]. Our results are compatible with changes in the composition of the membranes that make up the nuclear envelope, since phospholipids involved include phosphatidylethanolamine, phosphatidylcholine and phosphatidylinositol, all membrane components. Noteworthy, it shall be reminded that nuclear envelop leaflets are in continuity with endoplasmic reticulum membranes. Therefore, changes in nuclear envelope can be related with dysfunctions in this membranous organelle, already characterized in ALS[3,6,21]

DAG in nucleus has a signaling role, reviewed in [21], and it is derived from the activity of a PLCß1 isoform. In line with altered homeostasis of nuclear DAG in ALS, we detected different amounts of PLCß1 in tissue lysates from G93A mice and potentially from ALS patients. This enzyme is present in neuronal cells in rat brain [22], partially present in nuclei. Further, it is known that this enzyme is sensitive to endoplasmic reticulum stress[23], a well described pathogenic mediator in ALS[6]. Interestingly, a loss in PLCß1 has been also described in other neurodegenerative conditions linked to protein aggregation, such as Pick's disease [24] and Creutzfeld-Jacobs disease[25]. Furthermore, PLCß1 loss induces an age-dependent loss of neurites and neurodegeneration[26]. Nonetheless, it is known that metabotropic glutamate receptors regulate synaptic transmission through the stimulation of PLCß1 [27]. Of note, activation of metabotropic signaling has been proposed as novel potentially therapeutic strategy in ALS[28]. DAG build-up in nucleus leads to PKCßII nuclear translocation[21]. For this reason, we evaluated whether, in line with altered DAG and PLCß1 levels in ALS, this disease is associated with changes in PKCßII. The results indicate that, both in ALS patients and in G93A mice, PKCßII levels are diminished. Up to date, no previous evidence of its involvement in this disease were known, except with the fact that PKC levels were increased in ALS patients [29]. The involvement of the potential loss of PKCBII in ALS pathogenesis can be diverse, as this protein interacts with mitochondria[30], and with autophagic function[31], to name a few, and both elements are involved in ALS [32,33]

Other changes in lipid components of nuclei include plasmalogens. These membrane glycerophospholipids contain a fatty alcohol with a vinyl-ether bond at the sn-1 position, and they are enriched in polyunsaturated fatty acids at the sn-2 position of the glycerol backbone. For this reason, they have been involved in the redox 
bioRxiv preprint doi: https://doi.org/10.1101/682526; this version posted June 26, 2019. The copyright holder for this preprint (which was

not certified by peer review) is the author/funder, who has granted bioRxiv a license to display the preprint in perpetuity. It is made available under aCC-BY-NC-ND 4.0 International license.

homeostasis of membranes[34], and its Previous data have characterized plasmalogens in the nuclear envelope of postmytotic tissues such as myocardium [35]. Peroxisomes contribute to plasmalogen synthesis, and previous data of our group describe alterations in peroxisomal enzymes in ALS tissues [36]. Whether the loss of plasmalogen present in ALS nuclei is potentially derived from this peroxisomal disturbance and whether it contributes to ALS pathophysiology is still unknown. Nonetheless, AGPS intensity was strongly diminished in G93A mice motor neurons, supporting a potential involvement of this pathway in the pathophysiology of the spinal cord dysfunction present in these mice.

Among differential lipids, other classes are also present. These include triacylglycerides, which could be explained by changes in the so-called lipid droplets, recently described in the nucleoplasm[37] where it may derive from inner nuclear membrane[38]. Since lipid droplet physiological role in nuclei is mainly unknown, we cannot infer its pathophysiological significance in our samples. Nonetheless, recent data disclose that glial cells accumulate lipid droplets as a response to excitotoxicity[39]. However, they may also play a role in neurodegeneration in lipid peroxidation-prone environments[40]. Our finding that no general effect (not all triaclyglycerides increase or decrease) is present, may be derived from potentially heterogeneous cellular source of the nuclei.

Similarly, another group of lipids with potential relevance are sphingolipids. Previous findings in the field suggest the importance of these lipids in ALS. In the G93A model, alterations are demonstrated in tissue levels during the development of the disease. Further, the administration of GM3, one of its members, leads to an improvement in the clinical course of the disease [41]. In a close relationship, it has been also shown that the transcription of glucosylceramide synthase is necessary for optimal protection against denervation, and that its inhibition worsens the clinical course in another model of the family ALS, the mouse hSODG86R [42] . Our results are fully compatible with these data, as we found significantly decreased levels of two molecules compatible with glucosylceramide identity. As these molecules are functionally involved in cell signaling, autophagy and determination of lipid membrane functional domains [43,44], its potential role in ALS pathophysiology merits further investigation.

We acknowledge, as a limitation of our work, the low number of individuals used. However, even with such a limitation, the profiling of a high number of nuclei is possible, and allows to distinction of clear lipidomic 
bioRxiv preprint doi: https://doi.org/10.1101/682526; this version posted June 26, 2019. The copyright holder for this preprint (which was

not certified by peer review) is the author/funder, who has granted bioRxiv a license to display the preprint in perpetuity. It is made available under aCC-BY-NC-ND 4.0 International license.

profiles. Further, the high heterogeneity of nuclear structures does not permit to attribute these changes to a specific cell subtype. Similarly, we do not know if freezing procedures have led to a selective enrichment of given cellular types or nuclei. Thus, we cannot exclude that specific nuclei can be more resistant to postmortem changes and criopreservation. However, we assume the fact that nuclei enrichment is robust, based on the absence of mitochondrial markers -major contaminants in similar procedures-, and the morphological and biochemical evidences for nuclear presence. Despite these limitations, changes in two lipid families (plasmalogen and DAG) were independently validated by exploring their potential molecular basis. We think that the combination of the described technologies (lipidomic analyses applied to subcellular fractionation of pathologically relevant samples) could pave the way for the discovery of novel biomarkers and pathophysiologically relevant pathways.

\section{DECLARATIONS}

\section{Ethics approval and consent to participate}

Samples from human individuals were obtained from the Institute of Neuropathology and HUB-ICO-IDIBELL Brain Bank following the guidelines of the local ethics committees. Experiments with mice were approved Institutional Animal Care Committee of IRBLleida and were conformed to the Directive 2010/63/EU of the European Parliament.

\section{Consent for publication}

Not aplicable

\section{Availability of data and material}

The Orbismet, the R package employed for analyses of lipidomic data during the current study are available in the UOC repository, at in http://hdl.handle.net/10609/65305

\section{Competing interests}

The authors declare that they have no competing interests

\section{Funding}

This work was supported by the Seventh Framework Programme of the European Commission, [grant agreement 278486: DEVELAGE to IF]; by the the Autonomous Goverment of Catalunya [2017SGR696] and the Spanish Ministry of Health [PI14/1115, 14/003218 PI17-00134]; and the "Marató de TV3" Foundation (PP00111). MJ is a Serra Hunter program fellow. RRG is a fellow from Marie Curie Cofund IRBLleida-IPP

(EU $7^{\text {th }}$ Framework Program, 609396 agreement). PT is a predoctoral fellow from Spanish Ministry of 
bioRxiv preprint doi: https://doi.org/10.1101/682526; this version posted June 26, 2019. The copyright holder for this preprint (which was not certified by peer review) is the author/funder, who has granted bioRxiv a license to display the preprint in perpetuity. It is made available under aCC-BY-NC-ND 4.0 International license.

Education [FPU16/01446]. LF, CR and OR-N are predoctoral fellows from the Autonomous Government of

Catalonia. Supported also by a FUNDELA Grant, RedELA-Plataforma Investigación and the Fundació Miquel Valls (Jack Van den Hoek donation). FEDER funds are acknowledged (“A way to make Europe”)

\section{Authors' contributions}

OR-N,MJ and PT optimized the nuclei isolation, and performed western-blot analyses. MJ and JS performed lipidomic data, designed R packages and analyzed these data. RR-G,PA-B, LF and CR generated transgenic mice, maintained iPSc and characterized motor neurons and derived results. VA,MP and JB performed general data analyses. RP, IF and MP-O planned the experiments, curated data, drafted the manuscript and prepared figures. All authors read and approved the final manuscript.

\section{Acknowledgements}

We are indebted to tissue donors and their families.

\section{REFERENCES}

Bibliography

1. Ayala V, Granado-Serrano AB, Cacabelos D, Naudí A, Ilieva EV, Boada J, Caraballo-Miralles V, Lladó J, Ferrer I, Pamplona R, et al. (2011) Cell stress induces TDP-43 pathological changes associated with ERK1/2 dysfunction: implications in ALS. Acta Neuropathol 122: 259-270.

2. Chou C-C, Zhang Y, Umoh ME, Vaughan SW, Lorenzini I, Liu F, Sayegh M, Donlin-Asp PG, Chen YH, Duong DM, et al. (2018) TDP-43 pathology disrupts nuclear pore complexes and nucleocytoplasmic transport in ALS/FTD. Nat Neurosci 21: 228-239.

3. Gautam M, Jara JH, Kocak N, Rylaarsdam LE, Kim KD, Bigio EH, Hande Özdinler P (2018) Mitochondria, ER, and nuclear membrane defects reveal early mechanisms for upper motor neuron vulnerability with respect to TDP-43 pathology. Acta Neuropathol.

4. Fitzgerald KC, O’Reilly ÉJ, Falcone GJ, McCullough ML, Park Y, Kolonel LN, Ascherio A (2014) Dietary $\omega-3$ polyunsaturated fatty acid intake and risk for amyotrophic lateral sclerosis. JAMA Neurol 71: 1102-1110.

5. Farooqui AA, Ong W-Y, Farooqui T (2010) Lipid mediators in the nucleus: Their potential contribution to Alzheimer's disease. Biochim Biophys Acta 1801: 906-916.

6. Ilieva EV, Ayala V, Jové M, Dalfó E, Cacabelos D, Povedano M, Bellmunt MJ, Ferrer I, Pamplona R, Portero-Otín M (2007) Oxidative and endoplasmic reticulum stress interplay in sporadic amyotrophic lateral sclerosis. Brain 130: 3111-3123.

7. Cacabelos D, Ayala V, Ramírez-Nunez O, Granado-Serrano AB, Boada J, Serrano JCE, Cabré R, NadalRey G, Bellmunt MJ, Ferrer I, et al. (2014) Dietary lipid unsaturation influences survival and oxidative modifications of an amyotrophic lateral sclerosis model in a gender-specific manner. Neuromolecul Med 16: 669-685.

8. Du Z-W, Chen H, Liu H, Lu J, Qian K, Huang C-L, Zhong X, Fan F, Zhang S-C (2015) Generation and expansion of highly pure motor neuron progenitors from human pluripotent stem cells. Nat Commun 6 : 6626.

9. Blobel G, Potter VR (1966) Nuclei from rat liver: isolation method that combines purity with high yield. Science 154: 1662-1665.

10. Jové M, Moreno-Navarrete JM, Pamplona R, Ricart W, Portero-Otín M, Fernández-Real JM (2014) Human omental and subcutaneous adipose tissue exhibit specific lipidomic signatures. FASEB J 28: 1071-1081.

11. Grimm MOW, Kuchenbecker J, Rothhaar TL, Grösgen S, Hundsdörfer B, Burg VK, Friess P, Müller U, Grimm HS, Riemenschneider M, et al. (2011) Plasmalogen synthesis is regulated via alkyl- 
bioRxiv preprint doi: https://doi.org/10.1101/682526; this version posted June 26, 2019. The copyright holder for this preprint (which was not certified by peer review) is the author/funder, who has granted bioRxiv a license to display the preprint in perpetuity. It is made available under aCC-BY-NC-ND 4.0 International license.

dihydroxyacetonephosphate-synthase by amyloid precursor protein processing and is affected in Alzheimer's disease. J Neurochem 116: 916-925.

12. Starodub O, Jolly CA, Atshaves BP, Roths JB, Murphy EJ, Kier AB, Schroeder F (2000) Sterol carrier protein-2 localization in endoplasmic reticulum and role in phospholipid formation. Am J Physiol Cell Physiol 279: C1259-69.

13. Benador IY, Veliova M, Mahdaviani K, Petcherski A, Wikstrom JD, Assali EA, Acín-Pérez R, Shum M, Oliveira MF, Cinti S, et al. (2018) Mitochondria Bound to Lipid Droplets Have Unique Bioenergetics, Composition, and Dynamics that Support Lipid Droplet Expansion. Cell Metab 27: 869-885.e6.

14. Nishimura AL, Mitne-Neto M, Silva HCA, Richieri-Costa A, Middleton S, Cascio D, Kok F, Oliveira JRM, Gillingwater T, Webb J, et al. (2004) A mutation in the vesicle-trafficking protein VAPB causes late-onset spinal muscular atrophy and amyotrophic lateral sclerosis. Am J Hum Genet 75: 822-831.

15. Boeynaems S, Bogaert E, Van Damme P, Van Den Bosch L (2016) Inside out: the role of nucleocytoplasmic transport in ALS and FTLD. Acta Neuropathol 132: 159-173.

16. Mészáros N, Cibulka J, Mendiburo MJ, Romanauska A, Schneider M, Köhler A (2015) Nuclear pore basket proteins are tethered to the nuclear envelope and can regulate membrane curvature. Dev Cell 33: 285-298.

17. Floch AG, Tareste D, Fuchs PFJ, Chadrin A, Naciri I, Léger T, Schlenstedt G, Palancade B, Doye V (2015) Nuclear pore targeting of the yeast Pom33 nucleoporin depends on karyopherin and lipid binding. J Cell Sci 128: 305-316.

18. Stavru F, Nautrup-Pedersen G, Cordes VC, Görlich D (2006) Nuclear pore complex assembly and maintenance in POM121- and gp210-deficient cells. J Cell Biol 173: 477-483.

19. Doucet CM, Hetzer MW (2010) Nuclear pore biogenesis into an intact nuclear envelope. Chromosoma 119: 469-477.

20. Patel SS, Rexach MF (2008) Discovering novel interactions at the nuclear pore complex using bead halo: a rapid method for detecting molecular interactions of high and low affinity at equilibrium. Mol Cell Proteomics 7: 121-131.

21. Irvine RF (2003) Nuclear lipid signalling. Nat Rev Mol Cell Biol 4: 349-360.

22. Montaña M, García del Caño G, López de Jesús M, González-Burguera I, Echeazarra L, Barrondo S, Sallés J (2012) Cellular neurochemical characterization and subcellular localization of phospholipase C $\beta 1$ in rat brain. Neuroscience 222: 239-268.

23. Yasuda E, Nagasawa K, Nishida K, Fujimoto S (2008) Decreased expression of phospholipase C-beta 1 protein in endoplasmic reticulum stress-loaded neurons. Biol Pharm Bull 31: 719-721.

24. Dalfó E, Albasanz JL, Rodríguez A, Martín M, Ferrer I (2005) Abnormal group I metabotropic glutamate receptor expression and signaling in the frontal cortex in Pick disease. J Neuropathol Exp Neurol 64: 638-647.

25. Rodríguez A, Freixes M, Dalfó E, Martín M, Puig B, Ferrer I (2005) Metabotropic glutamate receptor/phospholipase $\mathrm{C}$ pathway: a vulnerable target to Creutzfeldt-Jakob disease in the cerebral cortex. Neuroscience 131: 825-832.

26. Böhm D, Schwegler H, Kotthaus L, Nayernia K, Rickmann M, Köhler M, Rosenbusch J, Engel W, Flügge G, Burfeind P (2002) Disruption of PLC-beta 1-mediated signal transduction in mutant mice causes age-dependent hippocampal mossy fiber sprouting and neurodegeneration. Mol Cell Neurosci 21: 584-601.

27. Kim D, Jun KS, Lee SB, Kang NG, Min DS, Kim YH, Ryu SH, Suh PG, Shin HS (1997) Phospholipase C isozymes selectively couple to specific neurotransmitter receptors. Nature 389: 290-293.

28. Battaglia G, Bruno V (2018) Metabotropic glutamate receptor involvement in the pathophysiology of amyotrophic lateral sclerosis: new potential drug targets for therapeutic applications. Curr Opin Pharmacol 38: 65-71.

29. Hu JH, Zhang H, Wagey R, Krieger C, Pelech SL (2003) Protein kinase and protein phosphatase expression in amyotrophic lateral sclerosis spinal cord. $J$ Neurochem 85: 432-442.

30. Krupska O, Sarnowska A, Fedorczyk B, Gewartowska M, Misicka A, Zablocka B, Beresewicz M (2017) Ischemia/Reperfusion-Induced Translocation of PKC $\beta$ II to Mitochondria as an Important Mediator of a Protective Signaling Mechanism in an Ischemia-Resistant Region of the Hippocampus. Neurochem Res 42: 2392-2403.

31. Patergnani S, Marchi S, Rimessi A, Bonora M, Giorgi C, Mehta KD, Pinton P (2013) PRKCB/protein kinase C, beta and the mitochondrial axis as key regulators of autophagy. Autophagy 9: 1367-1385.

32. Torres P, Ramírez-Núñez O, Romero-Guevara R, Barés G, Granado-Serrano AB, Ayala V, Boada J, Fontdevila L, Povedano M, Sanchís D, et al. (2018) Cryptic exon splicing function of TARDBP interacts with autophagy in nervous tissue. Autophagy 14: 1398-1403.

33. Vandoorne T, De Bock K, Van Den Bosch L (2018) Energy metabolism in ALS: an underappreciated opportunity? Acta Neuropathol 135: 489-509. 
bioRxiv preprint doi: https://doi.org/10.1101/682526; this version posted June 26, 2019. The copyright holder for this preprint (which was

34. Lessig J, Fuchs B (2009) Plasmalogens in biological systems: their role in oxidative processes in biological membranes, their contribution to pathological processes and aging and plasmalogen analysis. Curr Med Chem 16: 2021-2041.

35. Albert CJ, Anbukumar DS, Monda JK, Eckelkamp JT, Ford DA (2007) Myocardial lipidomics. Developments in myocardial nuclear lipidomics. Front Biosci 12: 2750-2760.

36. Cacabelos D, Ayala V, Granado-Serrano AB, Jové M, Torres P, Boada J, Cabré R, Ramírez-Núñez O, Gonzalo H, Soler-Cantero A, et al. (2016) Interplay between TDP-43 and docosahexaenoic acid-related processes in amyotrophic lateral sclerosis. Neurobiol Dis 88: 148-160.

37. Farese RV, Walther TC (2016) Lipid droplets go nuclear. J Cell Biol 212: 7-8.

38. Romanauska A, Köhler A (2018) The Inner Nuclear Membrane Is a Metabolically Active Territory that Generates Nuclear Lipid Droplets. Cell 174: 700-715.e18.

39. Ioannou MS, Jackson J, Sheu S-H, Chang C-L, Weigel AV, Liu H, Pasolli HA, Xu CS, Pang S, Matthies D, et al. (2019) Neuron-Astrocyte Metabolic Coupling Protects against Activity-Induced Fatty Acid Toxicity. Cell.

40. Liu L, Zhang K, Sandoval H, Yamamoto S, Jaiswal M, Sanz E, Li Z, Hui J, Graham BH, Quintana A, et al. (2015) Glial lipid droplets and ROS induced by mitochondrial defects promote neurodegeneration. Cell 160: 177-190.

41. Dodge JC, Treleaven CM, Pacheco J, Cooper S, Bao C, Abraham M, Cromwell M, Sardi SP, Chuang WL, Sidman RL, et al. (2015) Glycosphingolipids are modulators of disease pathogenesis in amyotrophic lateral sclerosis. Proc Natl Acad Sci USA 112: 8100-8105.

42. Henriques A, Croixmarie V, Priestman DA, Rosenbohm A, Dirrig-Grosch S, D’Ambra E, Huebecker M, Hussain G, Boursier-Neyret C, Echaniz-Laguna A, et al. (2015) Amyotrophic lateral sclerosis and denervation alter sphingolipids and up-regulate glucosylceramide synthase. Hum Mol Genet 24: 7390 7405.

43. Guenther GG, Edinger AL (2009) A new take on ceramide: starving cells by cutting off the nutrient supply. Cell Cycle 8: 1122-1126.

44. Cascianelli G, Villani M, Tosti M, Marini F, Bartoccini E, Magni MV, Albi E (2008) Lipid microdomains in cell nucleus. Mol Biol Cell 19: 5289-5295.

\section{FIGURE LEGENDS}

Fig. 1 Whole nuclei could be enriched from frozen spinal cords. a) Schematic procedure for obtention of a nuclei enriched fraction departing from frozen human spinal cords. b) Immunocytochemical evidence for nuclei integrity and heterogeneity, as shown by immunolabeling of nucleoporin (Mab414), by presence of neuron specific tubulin $\beta$ III (TubIII) and DAPI possitivity (in blue). c) Nuclei enriched fraction is depleted from cytosolic and other membrane containing organelle (such as mitochondria), as indicated by lack of immunoreactivity for mitochondrial markers (porin and mitofusin) and selective improvement in nuclear antigens (poly-ADP-ribose polimerase (PARP) and histone-H3)

Fig. 2 Nuclei from ALS patients exhibit a specific lipidome. Multivariate analyses including PCA (a), partial least square-discriminant analyses (b) and hierarchical clustering analyses (c, using lipids significantly affected by ALS status) demonstrate that nuclei from ALS patients exhibit a specific lipidomic profile. Upper panels are 
bioRxiv preprint doi: https://doi.org/10.1101/682526; this version posted June 26,2019 . The copyright holder for this preprint (which was

not certified by peer review) is the author/funder, who has granted bioRxiv a license to display the preprint in perpetuity. It is made available under aCC-BY-NC-ND 4.0 International license.

obtained by using lipids ionized in positive ionization, while as lower panels show the results using negative ionization

Fig. 3 Changes in nuclear DAG concentrations suggested by lipidomics are associated with alterations in PLCßI and PKCßII levels in ALS. Representative western-blot analyses of PKCßII in spinal cord lysates from ALS patients (a) and G93A mice (at terminal stage, 150 days, b) show that protein concentration is decreased in comparison with adequate control. Similarly, western-blot analyses of PLCßI are also decreased in spinal cord lysates from ALS patients (c) and G93A mice (d). In all panels, upper part shows representative western-blot images with lower part demonstrating quantification by densitometry, after normalization by Coomassie blue staining. Differences between groups were analyzed by Student's t test.

Fig. 4 Changes in nuclear plasmalogen concentrations suggested by lipidomics are associated with alterations in AGPS in human motor neurons and in G93A mice. Representative western-blot analyses of AGPS in spinal cord lysates from G93A mice (at terminal stage, 150 days, a) and ALS patients (b) show that protein concentration is decreased in G93A mice in comparison with adequate controls. c) confocal imaging of hIPs-derived motor neurons demonstrates decreased levels in cells derived from FUS mutants and C9orf72 IPs, as shown by quantiatiative analyses (see right panel in c); further, there was a significant correlation between AGPS cell content and nuclear perimeter (see below panels from each picture) both in control and in C9orf72 cells, but this was lost in FUS mutated cells. d) shows that confocal immunohistochemistry analyses of ventral regions of lumbar spinal cord section demonstrate a strong reactivity of AGPS in motor neurons in nontransgenic mice (arrows) in comparison with G93A mice (arrowheads). Motor neurons were identified by size, nuclear morphology and tubulin BIII immunoreactivity. Right panel in d shows quantitative analyses of AGPS immunoreactivity in these cells, compatible with decreased expression of this protein. In a) and b) panels, upper part shows representative western-blot images with lower part demonstrating quantification by densitometry, after normalization by Coomassie blue staining. Differences between groups were analyzed by Student's t test (a and d) and by ANOVA followed by Bonferroni post-hoc analyses in c. Bars in c and d are $10 \mu \mathrm{M}$ long. 
bioRxiv preprint doi: https://doi.org/10.1101/682526; this version posted June 26, 2019. The copyright holder for this preprint (which was not certified by peer review) is the author/funder, who has granted bioRxiv a license to display the preprint in perpetuity. It is made available under aCC-BY-NC-ND 4.0 International license.

Fig. 5 Changes in nuclear phospholipid and ether-phospholipids concentrations suggested by lipidomics are associated with alterations in SCP-2 in G93A mice. a) Confocal immunohistochemistry analyses of PMP70 in ventral regions of lumbar spinal cord sections, with an enrichment in PMP70 in motor neurons in G93A mice (at terminal stage, 150 days, arrows) in comparison with non-transgenic mice. Motor neurons were identified by size and nuclear morphology. b) As evidenced by western-blot analyses of PMP70 in spinal cord lysates, G93A mice do not show a general increase in PMP70 (quantification in e, after normalization by Coomassie blue staining). In line with potential ER/peroxisomal changes, immunoreactivity of SCP-2 is severely affected by G93A overexpression (c). While in non-Tg specimens, SCP-2 formed a perinuclear rim, this pattern is lost in G93A with enhancement in vesicular structures, specifically found in motor neurons. This is accompanied by an increase in the total lysate concentration of SCP-2, as shown by western blot analyses (in $\mathrm{d}$ and e). Differences between non-Tg and G93A were analyzed by Student's t test. Bars in A and C are $10 \mu \mathrm{M}$ long.

Fig. 6 Isolated nuclei show structures compatible with lipid droplets. Confocal image of isolated nuclei, showing Nile Red fluorescent vesicles both in the periphery of the nuclei (upper panel) or even inside the nuclear matrix (lower panel). Bars are $10 \mu \mathrm{M}$ long.

\section{TABLES}

Table 1

Characteristics of tissue donors.

\begin{tabular}{|l|l|l|l|l|l|}
\hline Gender & Age at death & Diagnosis & Disease & Disease & Postmortem \\
& & & onset & duration & delay \\
\hline M & 64 & ALS & Bulbar & 2 years & $16 \mathrm{~h} 30 \mathrm{~m}$ \\
\hline M & 57 & ALS & Bulbar & 2 years & $4 \mathrm{~h}$ \\
\hline F & 75 & ALS & Bulbar & 4 years & $4 \mathrm{~h} 5 \mathrm{~m}$ \\
\hline F & 79 & ALS & Bulbar & 20 months & $2 \mathrm{~h} 10 \mathrm{~m}$ \\
\hline
\end{tabular}




\begin{tabular}{|l|l|l|l|l|l|}
\hline M & 74 & - & - & - & $10 \mathrm{~h} 50 \mathrm{~m}$ \\
\hline $\mathrm{F}$ & 78 & - & - & - & $5 \mathrm{~h}$ \\
\hline $\mathrm{M}$ & 66 & - & - & - & $4 \mathrm{~h} 20 \mathrm{~m}$ \\
\hline $\mathrm{M}$ & 86 & - & - & - & $18 \mathrm{~h} 15 \mathrm{~m}$ \\
\hline
\end{tabular}

Table 2

Media used for human motor neuron differentiation from iPSC.

\begin{tabular}{|c|c|c|c|c|c|}
\hline Component|Media & NEPM & $\begin{array}{l}\text { MNP media } \\
\text { 1st }\end{array}$ & $\begin{array}{l}\text { MNP med } \\
2^{\text {nd }}\end{array}$ & $\begin{array}{l}\text { MN } \\
\text { induction } \\
\text { med }\end{array}$ & $\begin{array}{l}\text { MN } \\
\text { maturation } \\
\text { media }\end{array}$ \\
\hline DM/F12 & $20 \mathrm{ml}$ & $20 \mathrm{ml}$ & & & \\
\hline Neurobasal & $20 \mathrm{ml}$ & $20 \mathrm{ml}$ & & & \\
\hline Neurobasal + & & & $40 \mathrm{ml}$ & $40 \mathrm{ml}$ & $40 \mathrm{ml}$ \\
\hline B27+ supplement & $800 \mu \mathrm{l}$ & $800 \mu \mathrm{l}$ & $800 \mu \mathrm{l}$ & $800 \mu 1$ & $800 \mu 1$ \\
\hline Ascorbic acid & $0.1 \mathrm{mM}$ & $0.1 \mathrm{mM}$ & $0.1 \mathrm{mM}$ & $0.1 \mathrm{mM}$ & $0.1 \mathrm{mM}$ \\
\hline $\begin{array}{l}\text { L-Glutamine solution } \\
\text { (Thermo Scientific, \# } \\
\text { 25030024) }\end{array}$ & $1: 200$ & $1: 200$ & $1: 200$ & $1: 200$ & $1: 200$ \\
\hline $\begin{array}{l}\text { Non essential amino } \\
\text { acid solution (Sigma, } \\
\text { M7145) }\end{array}$ & $1: 100$ & $1: 100$ & $1: 100$ & - & - \\
\hline CHIR & $3 \mu \mathrm{M}$ & $1 \mu \mathrm{M}$ & $3 \mu \mathrm{M}$ & $3 \mu \mathrm{M}$ & \\
\hline SB43 & $2 \mu \mathrm{M}$ & $2 \mu \mathrm{M}$ & $2 \mu \mathrm{M}$ & $2 \mu \mathrm{M}$ & \\
\hline DMH1 & $2 \mu \mathrm{M}$ & $2 \mu \mathrm{M}$ & $2 \mu \mathrm{M}$ & $2 \mu \mathrm{M}$ & \\
\hline Retinoic acid & & $0.1 \mu \mathrm{M}$ & $0.1 \mu \mathrm{M}$ & $0.5 \mu \mathrm{M}$ & $0.5 \mu \mathrm{M}$ \\
\hline Purmorphamine & & $0.5 \mu \mathrm{M}$ & $0.5 \mu \mathrm{M}$ & $0.1 \mu \mathrm{M}$ & $0.1 \mu \mathrm{M}$ \\
\hline Valproic acid & & & $0.5 \mathrm{mM}$ & & \\
\hline Compound E & & & & & $0.1 \mu \mathrm{M}$ \\
\hline
\end{tabular}




\begin{tabular}{|c|c|c|c|c|c|}
\hline CNTF & & & & & $20 \mathrm{ng} / \mathrm{ml}$ \\
\hline IGF1 & & & & & $20 \mathrm{ng} / \mathrm{ml}$ \\
\hline $\begin{array}{l}\text { Penicillin/Streptromycin } \\
\text { (Thermo Scientific \# } \\
\text { 15140122) }\end{array}$ & $1: 400$ & $1: 400$ & $1: 400$ & $1: 400$ & $1: 400$ \\
\hline
\end{tabular}

Table 3

Antibodies and conditions used.

\begin{tabular}{|c|c|c|}
\hline Target & Dilution & Reference \\
\hline PARP & $1: 500$ in TBS-T $0.05 \%^{1}$ & sc-74470 (Santa Cruz Biotechnology) \\
\hline Histone H3 & $1: 500$ in TBS-T $0.05 \%$ & SAB4500352 (Sigma-Aldrich) \\
\hline Mitofusin 2 & $1: 1000$ in TBS-T $0.05 \%$ & M6319 (Sigma-Aldrich) \\
\hline Porin & $1: 1000$ in TBS-T $0.05 \%$ & ab15895 (Abcam) \\
\hline Lactate dehydrogenase & $1: 1000$ in TBS-T $0.05 \%$ & ab135396 (Abcam) \\
\hline $\begin{array}{l}\text { Nuclear Pore Complex Proteins } \\
\text { [Mab414] }\end{array}$ & $1: 250$ in PBS & ab50008 (Abcam) \\
\hline Tubulin $\beta \mathrm{III}$ & $1: 250$ in PBS & ab18207 (Abcam) \\
\hline AGPS & $\begin{array}{l}\text { 1:250 in TBS-T } 0.05 \% \text { for } \\
\text { western blot; } 1: 150 \text { in PBS } \\
\text { for immunofluorescence }\end{array}$ & sc-374201 (Santa Cruz Biotechnology) \\
\hline PLC $\beta I$ & $1: 250$ in TBS-T $0.05 \%$ & sc-5291 (Santa Cruz Biotechnology) \\
\hline PKC $\beta I I$ & $1: 250$ in TBS-T $0.05 \%$ & sc-13149 (Santa Cruz Biotechnology) \\
\hline SCP-2 & $1: 1000$ in TBS-T $0.05 \%$ & hpa027135 (Atlas Antibodies) \\
\hline PMP70 & $1: 250$ in PBS & Ab3421 (Abcam) \\
\hline $\begin{array}{l}\text { Mouse IgG, Alexa Fluor }{ }^{\circledR} 488 \\
\text { conjugate }\end{array}$ & 1:800 in PBS & A-11001 (Thermo Fisher Scientific) \\
\hline
\end{tabular}


bioRxiv preprint doi: https://doi org/101101/682526; this version posted June 26, 2019. The copyright holder for this preprint (which was not certified by peer review) is the author/funder, who has granted bioRxiv a license to display the preprint in perpetuity. It is made available under aCC-BY-NC-ND 4.0 International license.

\begin{tabular}{|l|l|l|}
\hline Rabbit IgG, Alexa Fluor ${ }^{\circledR} 546$ & $1: 800$ in PBS & A-11010 (Thermo Fisher Scientific) \\
\hline $\begin{array}{l}\text { Rabbit IgG, horseradish peroxidase } \\
\text { conjugate }\end{array}$ & $1: 50000$ in TBS-T 0.05\% & 31460 (Thermo Fisher Scientific) \\
\hline $\begin{array}{l}\text { Rabbit IgG, horseradish peroxidase } \\
\text { conjugate }\end{array}$ & $1: 30000$ in TBS-T 0.05\% & NA931V (Sigma) \\
\hline
\end{tabular}

${ }^{1}$ TBS-T 0.05\%: Tris Buffered Saline with Tween-20 0.05\%

Table 4

Differential lipids in nuclei isolated from ALS patients in comparison to non-ALS

\begin{tabular}{|c|c|c|}
\hline Potential ID ${ }^{1}$ & $\mathrm{P}$ value ${ }^{2}$ & $\begin{array}{l}\text { Change(ALS } \\
\text { vs non-ALS) }\end{array}$ \\
\hline \multicolumn{3}{|l|}{ Diacylglycerols } \\
\hline $\operatorname{DG}(34: 2)^{3}[$ iso2 $]$ & 0,017499 & down \\
\hline $\mathrm{DG}(46: 3) / \mathrm{CE}(24: 0)$ & 0,027414 & down \\
\hline $\operatorname{DG}(36: 0)^{3}$ & 0,023379 & down \\
\hline $\operatorname{DG}(36: 2)^{3}$ & 0,010411 & down \\
\hline $\mathrm{DG}(39: 7)\left[{ }^{3} / \mathrm{PA}(\mathrm{O}-32: 0)\right.$ & 0,007198 & up \\
\hline $\operatorname{DG}(35: 1)^{3}$ & 0,025619 & up \\
\hline $\operatorname{DG}(36: 0)^{3}$ & 0,001003 & up \\
\hline $\operatorname{DG}(38: 0)^{3}$ & 0,002498 & up \\
\hline $\operatorname{DG}(39: 6)^{3}$ & 0,034444 & up \\
\hline \multicolumn{3}{|l|}{ Glycerophospholipids } \\
\hline PA(18:0) & 0,024149 & down \\
\hline $\mathrm{PA}(\mathrm{O}-36: 3)) / \mathrm{PG}(\mathrm{O}-29: 0)$ & 0,043124 & down \\
\hline
\end{tabular}




\begin{tabular}{|c|c|c|}
\hline $\mathrm{PG}(\mathrm{P}-40: 2) / \mathrm{PG}(\mathrm{O}-40: 3)$ & 0,027358 & down \\
\hline $\mathrm{PS}(\mathrm{O}-40: 1) / \mathrm{PS}(\mathrm{P}-40: 0) / \mathrm{PS}(39: 1) /$ & 0,015925 & down \\
\hline PE(P-42:1)/ PE(O:42:2)/PE(42:1)/GlcCer(d36:0)/PC(39:1) & 0,029046 & down \\
\hline $\mathrm{PA}(\mathrm{O}-32: 0)$ & 0,024342 & up \\
\hline $\mathrm{PA}(\mathrm{P}-37: 0) / \mathrm{PG}(32: 0) / \mathrm{PA}(38: 5)$ & 0,018452 & up \\
\hline $\mathrm{PA}(\mathrm{P}-35: 1)$ & 0,018294 & up \\
\hline $\mathrm{PC}(\mathrm{O}-24: 0)$ & 0,0235 & up \\
\hline $\mathrm{PE}(42: 10) / \mathrm{PI}(31: 1)$ & $5,35 \mathrm{E}-05$ & up \\
\hline $\begin{array}{l}\mathrm{PE}(\mathrm{O}-37: 1) / \quad) / \mathrm{PC}(\mathrm{P}-33: 2) / \mathrm{PE}(\mathrm{P}-36: 2) / \mathrm{PE}(\mathrm{O}-36: 3) / \text { Cerebroside } \mathrm{B} / \\
\text { GlcCer(35:2)/CerP(42:2) }\end{array}$ & 0,024172 & up \\
\hline $\mathrm{PE}(\mathrm{P}-38: 3) / \mathrm{PE}(38: 3) / \mathrm{PC}(\mathrm{O}-35: 4) / \mathrm{PE}-\mathrm{NMe} 2(36: 2) / \mathrm{PE}(\mathrm{O}-38: 4$ & $4,76 \mathrm{E}-04$ & up \\
\hline PG(33:2) & 0,025597 & up \\
\hline PG(O-38:1)/PG(P-38:0)/PG(38:0)/TG(48/8) & 0,025968 & up \\
\hline PG(P-37:1)/PG(O-37:2) & 0,022001 & up \\
\hline $\mathrm{PS}(\mathrm{P}-38: 4) / \mathrm{PS}(\mathrm{O}-38: 5) / \mathrm{PI}(\mathrm{O}-32: 0) / \mathrm{PC}(37: 4) / \mathrm{PE}(40: 4)$ & 0,01172 & up \\
\hline $\mathrm{PS}(\mathrm{P}-38: 4) / \mathrm{PS}(\mathrm{O}-38: 5)$ & 0,025977 & up \\
\hline $\mathrm{PE}(\mathrm{P}-38: 3) / \mathrm{PE}(38: 3) / \mathrm{PC}(\mathrm{O}-35: 4) / \mathrm{PE}(\mathrm{O}-38: 4) /$ Cerebroside $\mathrm{C} /$ & 0,011598 & up \\
\hline \multicolumn{3}{|l|}{ Triacylglycerols } \\
\hline TG(46:1) & 0,029092 & down \\
\hline TG(48:2) & 0,028442 & down \\
\hline TG(50:3)/PG(41:0) & 0,027652 & down \\
\hline TG(60:7) & 0,019288 & down \\
\hline TG(43:3)/PE-Cer(39:1)/SM(36:1)/PA(P-39:0)/PA(O-39:1) & 0,027467 & down \\
\hline $\mathrm{TG}(54: 3)$ & 0,01669 & up \\
\hline TG(65:12) & 0,001038 & up \\
\hline TG(50:0) & 0,027069 & up \\
\hline TG(59:9) & 0,00401 & up \\
\hline TG(65:2) & 0,001892 & up \\
\hline Sphingolipids & & \\
\hline
\end{tabular}


bioRxiv preprint doi: https://doi.org/10.1101/682526; this version posted June 26, 2019. The copyright holder for this preprint (which was not certified by peer review) is the author/funder, who has granted bioRxiv a license to display the preprint in perpetuity. It is made available under aCC-BY-NC-ND 4.0 International license.

\begin{tabular}{|l|l|l|}
\hline Cer(d35:0) & 0,027563 & down \\
\hline GlcCer(d42:1)/PC(38:1)/PE(41:1) & 0,026204 & down \\
\hline Cer(46:0) & 0,007346 & up \\
\hline LacCer(d34:0)/PC(42:5)/Ins-1-P-Cer(40:1)/C22 Sulfatide & 0,025398 & up \\
\hline
\end{tabular}

${ }^{1}$ LIPID-MAPS nomenclature, identification has been proposed on basis of isotope distribution and identity of retention times with those of representative standards, except in ${ }^{3}$ where identity was confirmed by MS/MS; ${ }^{2} \mathrm{p}$ value after $\mathrm{T}$ test for differences 
bioRxiv preprint doi: https://doi.org/10.1101/682526; this version posted June 26, 2019. The copyright holder for this preprint (which was not certified by peer review) is the author/funder, who has granted bioRxiv a license to display the preprint in perpetuity. It is made available under aCC-BY-NC-ND 4.0 International license. 


\section{Figure 1}

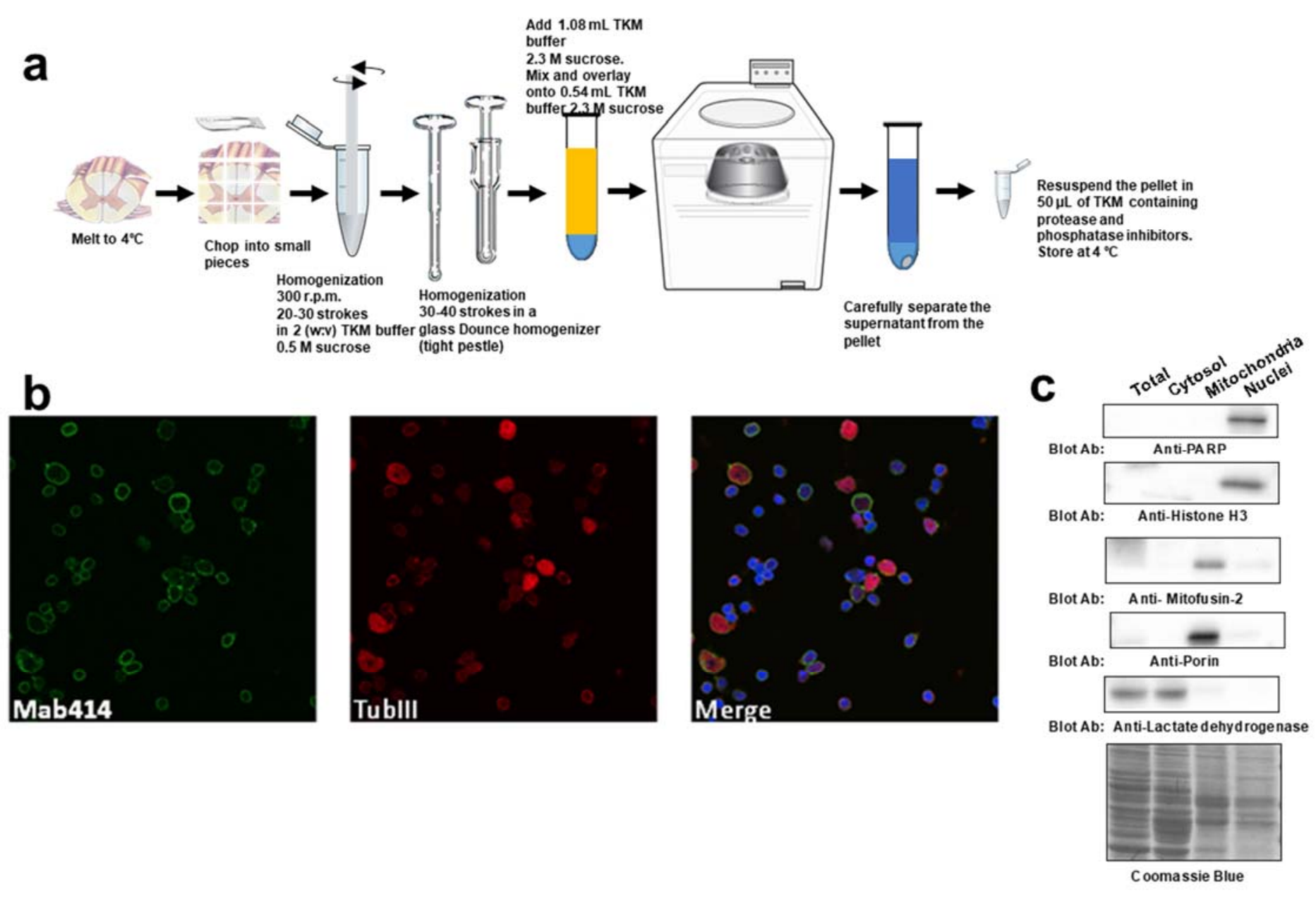




\section{Figure 2}

a

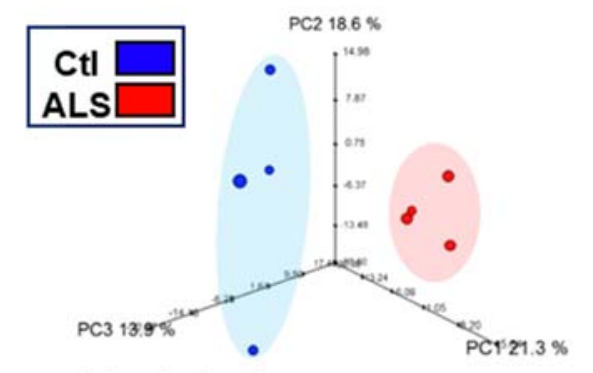

Positive ionization

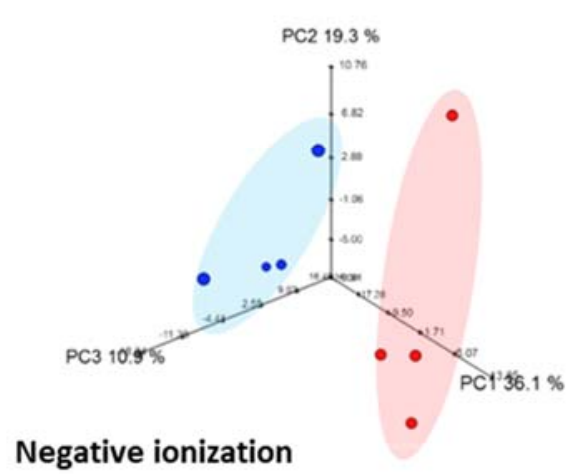

b
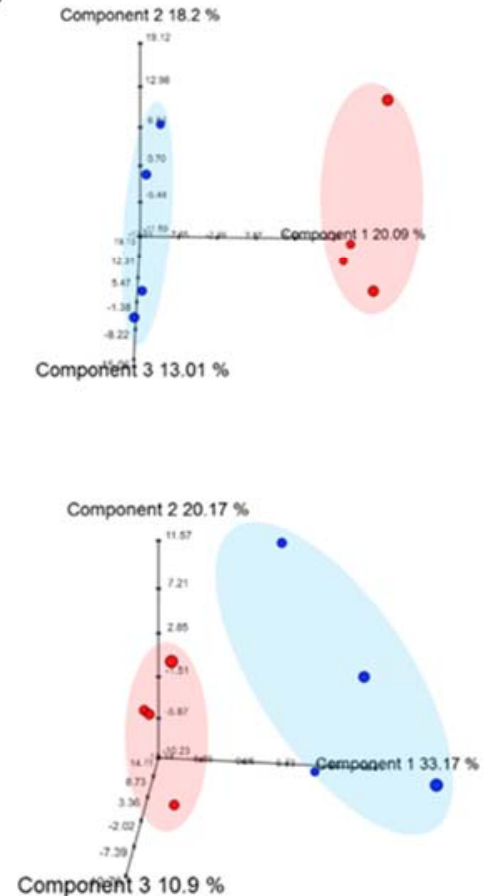

c
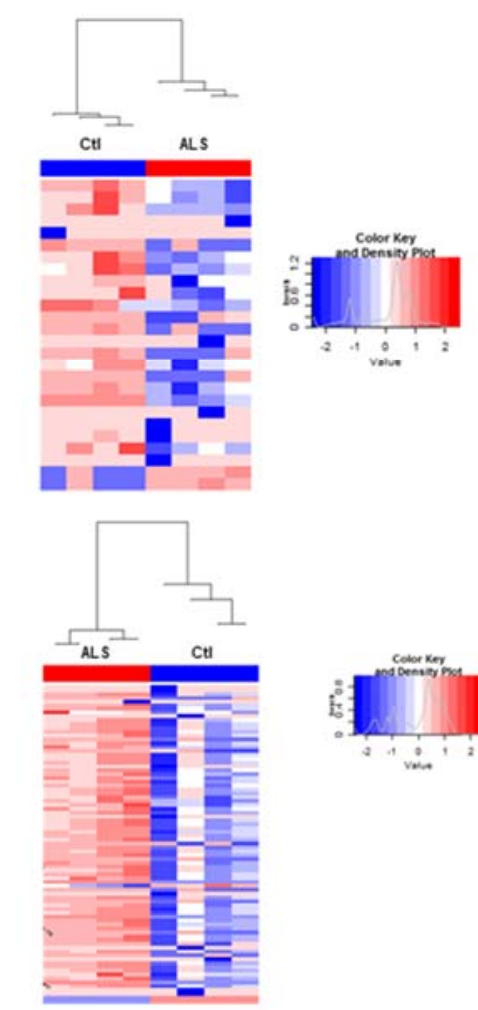
bioRxiv preprint doi: https://doi org/10 1101/682526; this version posted June 26,2019 . The copyright holder for this preprint (which was not certified by peer review) is the author/funder, who has granted bioRxiv a license to display the preprint in perpetuity. It is made available under aCC-BY-NC-ND 4.0 International license.

\section{Figure 3}

a

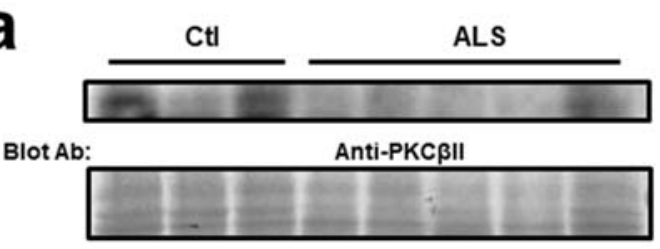

Coomassie Blue

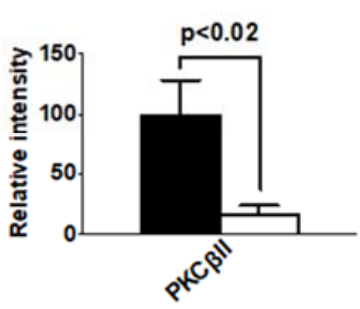

C

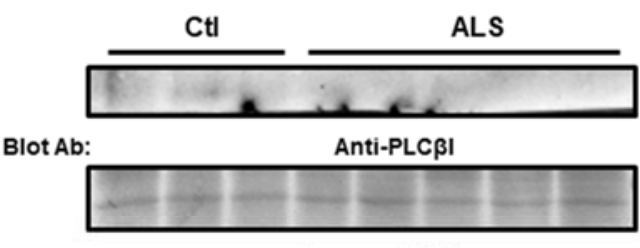

Coomassie Blue

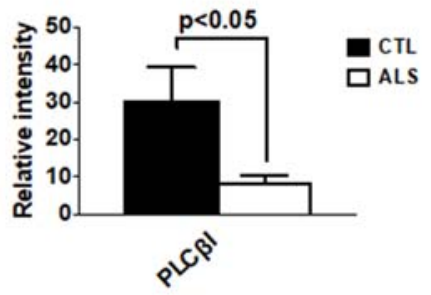

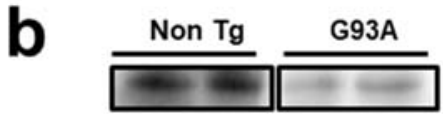

Blot Ab:

Anti-PKC $\beta$ II

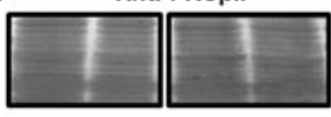

Coomassie Blue
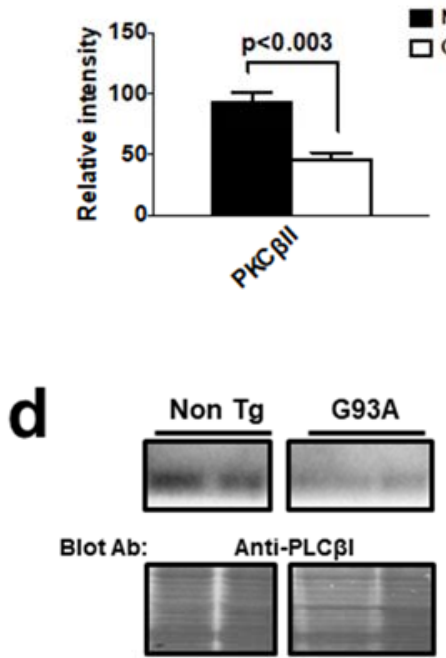

Coomassie Blue

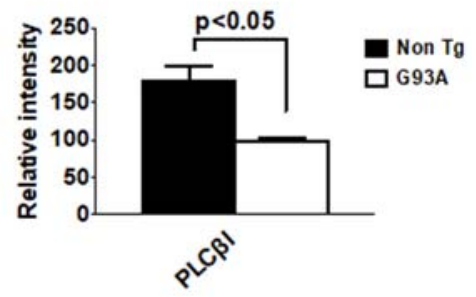


bioRxiv preprint doi: https://doi.org/10 1101/682526; this version posted June 26 2019. The copyright holder for this preprint (which was not certified by peer review) is the author/funder, who has granted bioRxiv a license to display the preprint in perpetuity. It is made available under aCC-BY-NC-ND 4.0 International license.

\section{Figure 4}

a
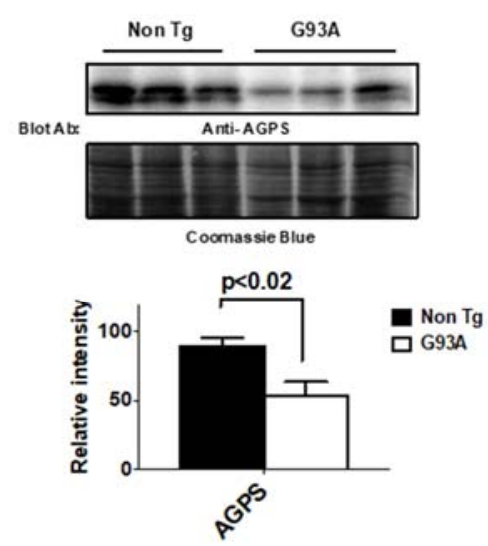

C Ctl
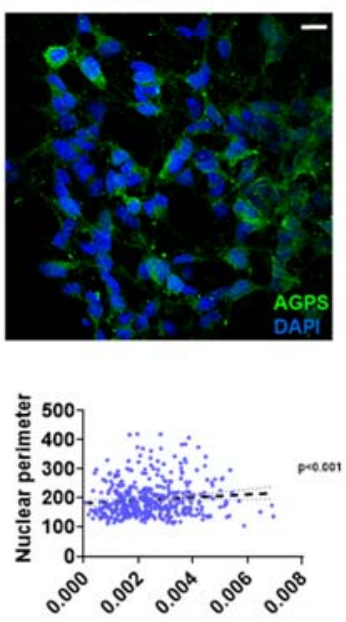

Cellular AGPS
FUS
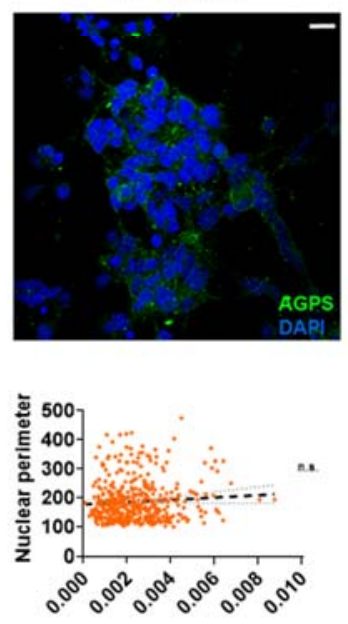

Cellular AGPS

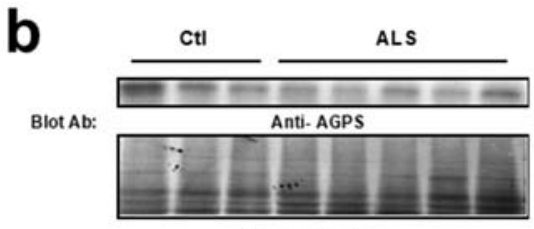

Coomassie Blue

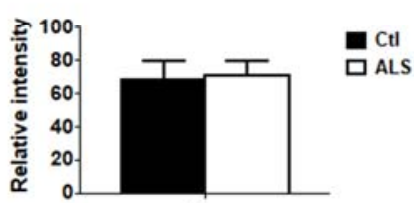

$8^{8^{5}}$

\section{c9orf72}
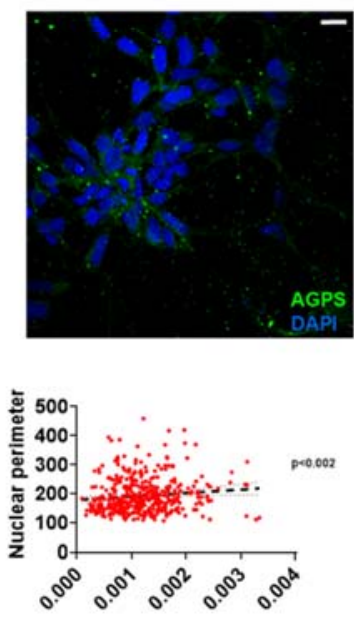

Cellular AGPS

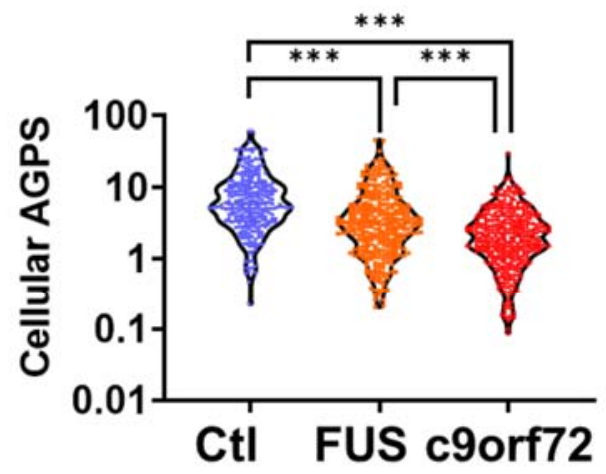

d
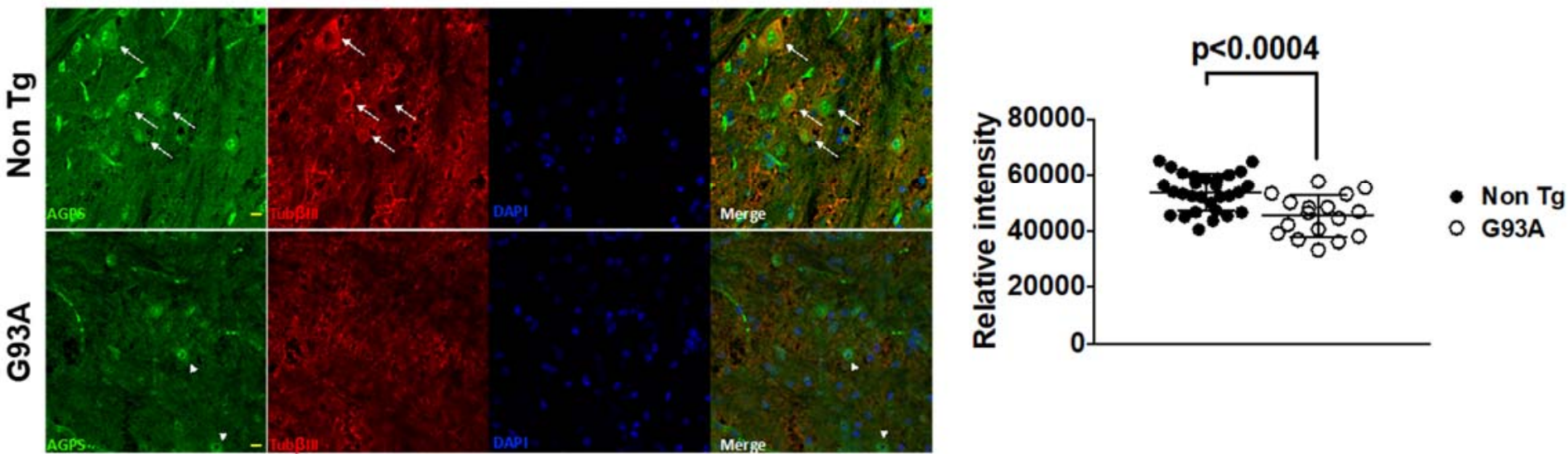


\section{Figure 5}

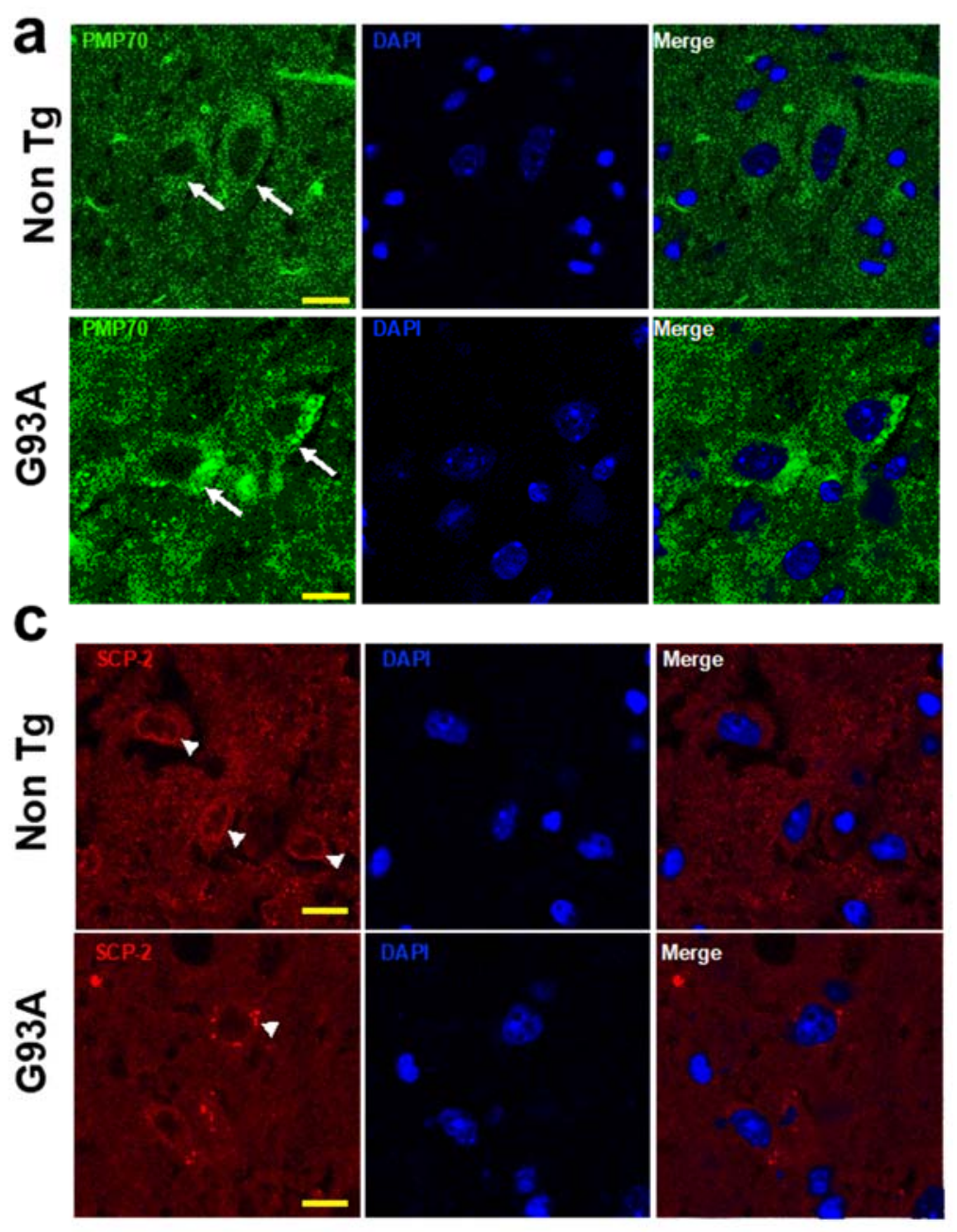

b
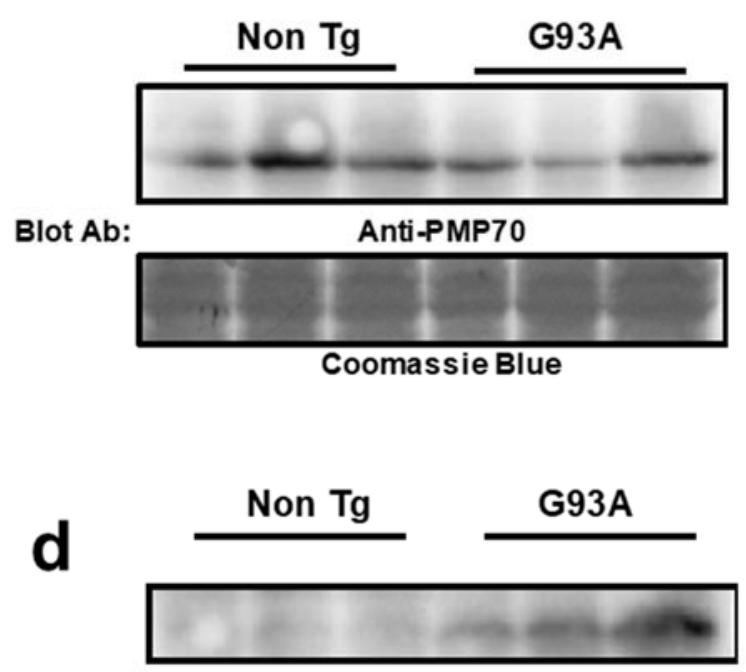

Blot Ab:

Anti-SCP-2

e
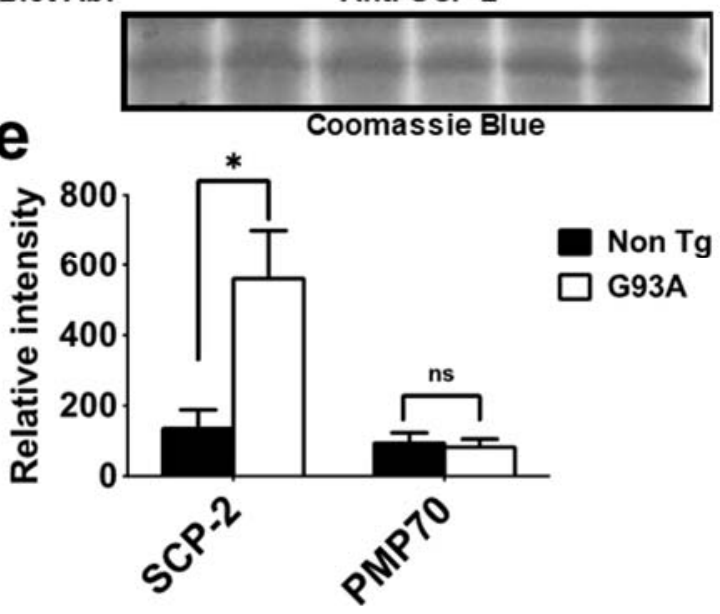

Non $\mathrm{Tg}$

G93A 
bioRxiv preprint doi: https://doi.org/10.1101/682526; this version posted June 26, 2019. The copyright holder for this preprint (which was not certified by peer review) is the author/funder, who has granted bioRxiv a license to display the preprint in perpetuity. It is made available under aCC-BY-NC-ND 4.0 International license.

\section{Figure 6}

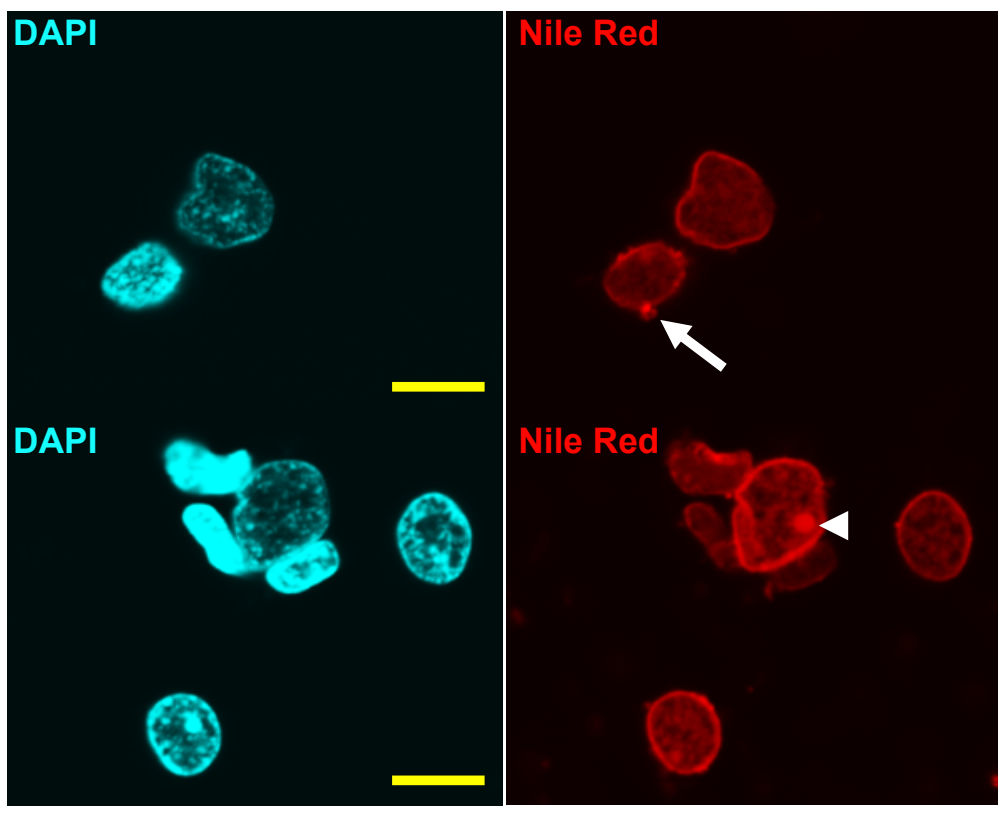




\section{Compound}

392.2951@10.1815

719.6055@9.690249

PE42:10) / PS(38:4) / PI(31:1)

935.5716@10.32

823.4462@9.345625

591.5298@9.67875

537.5588@9.947374

PE-NMe2(36:2) / Cerebroside C / PE(P-38:3) / PC(O-35:4) / PE(O-38:4)

509.528@9.689125

795.4147@9.01925

613.7038@7.652

879.5086@9.887375

$\mathrm{DG}(36: 0)$

781.4012@9.0195

$566.6927 @ 7.651$

851.4783@9.62225

240.2442@10.41038

495.5118@9.529125

567.6986@7.6485

242.2597@10.41013

798.3992@9.020625

809.4308@9.34525

567.4859@9.679249

907.5388@10.11962

647.5615@9.68425

633.5588@8.513376

481.4959@9.373624

942.7914@10.43637

645.4982@9.685876

TG(59:9)

767.3841@8.648625

634.5134@7.888876

882.4914@9.886624

Cer(d46:0)

242.2601@7.887875

725.3374@8.226375

572.5035@7.988875

739.353@8.226999

506.5045@7.88725

753.3713@8.647875

508.5217@7.88775

605.5148@9.677375

673.5342@9.6826

643.4132@9.6798

896.7988@5.293799

689.6095@9.6846 
836.7786@10.0204

697.3067@7.739801

808.7509@10.409

711.3218@7.7455

478.5098@10.40963

654.543@8.578875

1062.8143@10.766999

1025.0608@9.682

1019.0572@9.681625

TG(65:12)

883.8483@9.727125

C35 H68 O4 - 6.345625

C35 H69 N 07

941.6179@6.7009997

$\mathrm{PA}(\mathrm{P}-35: 1)$

$\mathrm{C} 35 \mathrm{H} 68 \mathrm{O} 4$

548.0226@9.683

LacCer(d34:0)

$\mathrm{C} 20 \mathrm{H} 38 \mathrm{Cl} \mathrm{N9} \mathrm{O} 10 \mathrm{~S}$

PG(33:2)

608.515@9.676999

C33 H69 N3 O 
$\mathrm{PA}(0-36: 3)$

Cerebroside C / PE(P-38:3) / PC(O-35:4) / PE(O-38:4)

$\mathrm{PI}(0-32: 0) / \mathrm{PE}(40: 4) / \mathrm{PC}(37: 4)$

$\mathrm{PS}(39: 1) / \mathrm{PS}(0-40: 1) / \mathrm{PS}(\mathrm{P}-40: 0)$

$\mathrm{DG}(34: 2)$

$\mathrm{TG}(60: 7)$

856.8291@10.62438

$\mathrm{C} 17 \mathrm{H} 40 \mathrm{~N} 6 \mathrm{O} 2$

$\mathrm{PA}(\mathrm{P}-37: 0)$

$\mathrm{C} 15 \mathrm{H} 27 \mathrm{~N} 5$

$\mathrm{DG}(32: 0)$

$\mathrm{PE}(48: 0)$

C21 H45 N5

$\mathrm{PE}(\mathrm{O}-37: 1)$

903.8038@10.643

Glucosylceramide (d42:1)

$\mathrm{CE}(24: 0)$ 


\begin{tabular}{|l}
\hline \\
\hline $\operatorname{Cer}(\mathrm{d} 35: 0)$ \\
\hline \\
\hline $\mathrm{TG}(50: 3)$ \\
\hline \\
\hline $\mathrm{TG}(48: 2)$ \\
\hline $\mathrm{GlCCer(d42:0)}$ \\
\hline $\mathrm{TG}(46: 1)$ \\
\hline
\end{tabular}




\begin{tabular}{|c|c|c|c|c|}
\hline $\log F C$ & $\mathbf{p}$ & Regulation & FC & Abund Diff (Raw) \\
\hline-18.29531 & 9.46787E-15 & 321689.03 down & -321689 & -296709.34 \\
\hline 14.330662 & 2.70109E-11 & 20604.355 up & 20604.355 & 22338.002 \\
\hline 0.3022712 & $5.35038 \mathrm{E}-05$ & 1.2330841 up & 1.2330841 & 12307.934 \\
\hline 0.4281497 & 0.000179481 & 1.3455068 up & 1.3455068 & 8780.457 \\
\hline 0.3373814 & 0.000313269 & 1.2634612 up & 1.2634612 & 66141.05 \\
\hline 0.2663202 & 0.000353472 & 1.2027361 up & 1.2027361 & 37949.78 \\
\hline 0.2918873 & 0.00045163 & 1.2242408 up & 1.2242408 & 81996.31 \\
\hline 0.2676515 & 0.000476271 & 1.2038466 up & 1.2038466 & 244366.44 \\
\hline 0.1971655 & 0.000528097 & 1.1464437 up & 1.1464437 & 9519584 \\
\hline 0.247962 & 0.000738498 & 1.1875284 up & 1.1875284 & 46105.22 \\
\hline 0.3843689 & 0.000789941 & 1.3052887 up & 1.3052887 & 77908.05 \\
\hline 0.2968307 & 0.000944302 & 1.2284428 up & 1.2284428 & 30871.133 \\
\hline 0.2659974 & 0.001002614 & 1.2024671 up & 1.2024671 & 81224.625 \\
\hline 0.2742546 & 0.001153632 & 1.2093691 up & 1.2093691 & 10125.514 \\
\hline 0.1899328 & 0.001224027 & 1.1407106 up & 1.1407106 & 78520.69 \\
\hline 0.2368284 & 0.001269561 & 1.1783992 up & 1.1783992 & 38554.297 \\
\hline 0.4355783 & 0.001425651 & 1.3524529 up & 1.3524529 & 19754.68 \\
\hline 0.2540265 & 0.001465978 & 1.1925308 up & 1.1925308 & 46568.484 \\
\hline 0.1754923 & 0.001635774 & 1.1293497 up & 1.1293497 & 199240 \\
\hline 0.2594014 & 0.001716011 & 1.1969819 up & 1.1969819 & 52603.938 \\
\hline 0.2435737 & 0.001727314 & 1.1839217 up & 1.1839217 & 4261.241 \\
\hline 0.2414604 & 0.001904014 & 1.1821887 up & 1.1821887 & 12430.402 \\
\hline 0.2039666 & 0.00234749 & 1.151861 up & 1.151861 & 46603.812 \\
\hline 0.2285686 & 0.002423955 & 1.1716719 up & 1.1716719 & 14305.125 \\
\hline 0.5558435 & 0.002497559 & 1.4700279 up & 1.4700279 & 43906.15 \\
\hline 0.2173128 & 0.003505627 & 1.1625662 up & 1.1625662 & 357430.25 \\
\hline 0.2932372 & 0.003669221 & 1.2253867 up & 1.2253867 & 29396.71 \\
\hline 0.5801316 & 0.004009763 & 1.4949856 up & 1.4949856 & 8723.716 \\
\hline 0.6990976 & 0.004385273 & 1.623489 up & 1.623489 & 16319.041 \\
\hline 0.4774783 & 0.005379546 & 1.3923079 up & 1.3923079 & 6620.994 \\
\hline 0.1634058 & 0.005539431 & 1.1199279 up & 1.1199279 & 32828.64 \\
\hline 0.3394746 & 0.007197958 & 1.2652957 up & 1.2652957 & 15155.879 \\
\hline 0.1752267 & 0.007275474 & 1.1291418 up & 1.1291418 & 3385.4326 \\
\hline 0.3580788 & 0.007345918 & 1.2817179 up & 1.2817179 & 7310.084 \\
\hline 0.1522627 & 0.007694131 & 1.1113111 up & 1.1113111 & 40808.656 \\
\hline 0.29724 & 0.007980905 & 1.2287914 up & 1.2287914 & 5920.3984 \\
\hline 0.3211696 & 0.008076015 & 1.249343 up & 1.249343 & 8913.504 \\
\hline 0.1192103 & 0.010608972 & 1.0861402 up & 1.0861402 & 23971.531 \\
\hline 0.1899233 & 0.013492855 & 1.1407031 up & 1.1407031 & 4630.6406 \\
\hline 0.2688942 & 0.01398979 & 1.2048839 up & 1.2048839 & 7713.291 \\
\hline 0.1186428 & 0.014853423 & 1.085713 up & 1.085713 & 186070.75 \\
\hline 0.19807 & 0.016001929 & 1.1471627 up & 1.1471627 & 30542.516 \\
\hline 10.458794 & 0.019507704 & 1407.3774 up & 1407.3774 & 15544.826 \\
\hline 10.053368 & 0.020231474 & 1062.5887 up & 1062.5887 & 10946.303 \\
\hline 10.482759 & 0.020504646 & 1430.9519 up & 1430.9519 & 16313.437 \\
\hline 10.459054 & 0.021393746 & 1407.6315 up & 1407.6315 & 16400.215 \\
\hline
\end{tabular}




\begin{tabular}{|c|c|c|c|c|}
\hline 9.88291 & 0.02147479 & 944.17456 up & 944.17456 & 9688.325 \\
\hline 10.239968 & 0.021548705 & 1209.3099 up & 1209.3099 & 13472.254 \\
\hline 9.693098 & 0.021708582 & 827.77686 up & 827.77686 & 7917.038 \\
\hline 0.1072568 & 0.024238328 & 1.0771781 up & 1.0771781 & 14087.383 \\
\hline 0.1969139 & 0.027149547 & 1.1462438 up & 1.1462438 & 5494.1953 \\
\hline 0.3274932 & 0.03444416 & 1.2548311 up & 1.2548311 & 10787.836 \\
\hline-14.23055 & $9.58254 \mathrm{E}-13$ & 19223.04 down & -19223.04 & -17729.363 \\
\hline 14.412014 & $8.52619 E-12$ & 21799.6 up & 21799.6 & 23633.838 \\
\hline 13.484619 & $2.18989 \mathrm{E}-11$ & 11462.381 up & 11462.381 & 12426.362 \\
\hline 0.2754636 & 0.00052883 & 1.2103829 up & 1.2103829 & 2358656 \\
\hline 0.3807897 & 0.001037565 & 1.3020544 up & 1.3020544 & 35438.984 \\
\hline 0.1650462 & 0.001308356 & 1.121202 up & 1.121202 & 44652.766 \\
\hline 0.432534 & 0.001892372 & 1.349602 up & 1.349602 & 37389.67 \\
\hline 0.5440353 & 0.002141869 & 1.458045 up & 1.458045 & 8311.903 \\
\hline 0.2251273 & 0.006784787 & 1.1688803 up & 1.1688803 & 24337.11 \\
\hline 0.3945727 & 0.008297467 & 1.3145534 up & 1.3145534 & 13978.539 \\
\hline 0.2971216 & 0.008873323 & 1.2286905 up & 1.2286905 & 115504.72 \\
\hline-0.215548 & 0.010410988 & 1.1611445 down & -1.161145 & -5677.633 \\
\hline-0.280678 & 0.012372271 & 1.2147657 down & -1.214766 & -1966.8125 \\
\hline 0.2645808 & 0.016690265 & 1.2012869 up & 1.2012869 & 8771.291 \\
\hline 0.6036241 & 0.018294131 & 1.5195289 up & 1.5195289 & 9538.023 \\
\hline 0.1995873 & 0.019939106 & 1.1483698 up & 1.1483698 & 10893.824 \\
\hline 0.273346 & 0.020230094 & 1.2086077 up & 1.2086077 & 5842.6504 \\
\hline-11.40286 & 0.021313224 & 2707.7231 down & -2707.723 & -2496.4673 \\
\hline-11.52748 & 0.022939231 & 2951.9966 down & -2951.997 & -37045.53 \\
\hline-13.02247 & 0.023617232 & 8320.608 down & -8320.608 & -150396.84 \\
\hline-0.208895 & 0.02364707 & 1.1558024 down & -1.155802 & -4493.742 \\
\hline-11.13556 & 0.02414891 & 2249.7627 down & -2249.763 & -2074.0693 \\
\hline 11.258992 & 0.024290718 & 2450.7239 up & 2450.7239 & 2656.0442 \\
\hline 9.943075 & 0.02434156 & 984.3825 up & 984.3825 & 1066.2552 \\
\hline 10.488378 & 0.024457032 & 1436.5352 up & 1436.5352 & 1556.4735 \\
\hline 11.066494 & 0.024697773 & 2144.6016 up & 2144.6016 & 2324.1504 \\
\hline 11.624372 & 0.02506041 & 3157.0723 up & 3157.0723 & 3421.8584 \\
\hline 11.315565 & 0.025080454 & 2548.7341 up & 2548.7341 & 2762.304 \\
\hline 9.327595 & 0.025298784 & 642.51874 up & 642.51874 & 695.61035 \\
\hline 10.794524 & 0.025398463 & 1776.1333 up & 1776.1333 & 1924.6616 \\
\hline 10.314449 & 0.025425991 & 1273.3818 up & 1273.3818 & 1379.5837 \\
\hline 10.506367 & 0.025469834 & 1454.5597 up & 1454.5597 & 1576.0144 \\
\hline 9.624341 & 0.025549063 & 789.25134 up & 789.25134 & 854.6965 \\
\hline 11.656177 & 0.025596691 & 3227.4446 up & 3227.4446 & 3498.1528 \\
\hline 9.55644 & 0.02561899 & 752.9657 up & 752.9657 & 815.3555 \\
\hline 11.000752 & 0.025693204 & 2049.0684 up & 2049.0684 & 2220.573 \\
\hline 0.2186685 & 0.025736462 & 1.1636591 up & 1.1636591 & 8916.699 \\
\hline 11.316339 & 0.025968196 & 2550.1008 up & 2550.1008 & 2763.7856 \\
\hline 11.896506 & 0.025977213 & 3812.4595 up & 3812.4595 & 4132.4185 \\
\hline 0.340884 & 0.027068563 & 1.2665324 up & 1.2665324 & 4817.218 \\
\hline 0.2631978 & 0.032180473 & 1.200136 up & 1.200136 & 6826.1465 \\
\hline
\end{tabular}




\begin{tabular}{|c|c|c|c|c|}
\hline 0.1703036 & 0.034483775 & 1.1252953 up & 1.1252953 & 5812.5195 \\
\hline-0.070622 & 0.039186444 & 1.0501693 down & -1.050169 & 567.87695 \\
\hline 0.2115406 & 0.03973117 & 1.157924 up & 1.157924 & 4067.289 \\
\hline-0.685736 & 0.04312377 & 1.6085223 down & -1.608522 & -28952.445 \\
\hline 0.4922731 & 0.04570038 & 1.4066595 up & 1.4066595 & 12174.039 \\
\hline 0.4334636 & 0.049116958 & 1.3504719 up & 1.3504719 & 51009.453 \\
\hline 11.690846 & 0.011598373 & 3305.9436 up & 3305.9436 & 28635.693 \\
\hline 11.976217 & 0.011720145 & 4029.0312 up & 4029.0312 & 37497.65 \\
\hline-10.65984 & 0.015925 & 1617.8226 down & -1617.823 & -17041.242 \\
\hline-12.55013 & 0.016834518 & 5997.439 down & -5997.439 & -98068.49 \\
\hline-10.85686 & 0.017498925 & 1854.5525 down & -1854.553 & -20897.605 \\
\hline-9.989641 & 0.019287597 & 1016.6738 down & -1016.674 & -10038.737 \\
\hline-0.445942 & 0.035632934 & 1.3622036 down & -1.362204 & -759257 \\
\hline 12.730565 & 0.016436499 & 6796.4473 up & 6796.4473 & 82760.18 \\
\hline 10.624329 & 0.018451843 & 1578.4891 up & 1578.4891 & 14042.712 \\
\hline 10.180083 & 0.021526989 & 1160.14 up & 1160.14 & 1024.5553 \\
\hline 10.648276 & 0.021528255 & 1604.9097 up & 1604.9097 & 1417.7284 \\
\hline 10.731791 & 0.021985058 & 1700.5557 up & 1700.5557 & 1502.2788 \\
\hline 10.806344 & 0.022001365 & 1790.7448 up & 1790.7448 & 1582.0054 \\
\hline 11.637106 & 0.023172377 & 3185.0625 up & 3185.0625 & 2814.572 \\
\hline-10.07715 & 0.023353804 & 1080.2491 down & -1080.249 & -1221.0115 \\
\hline-11.43544 & 0.023378903 & 2769.5654 down & -2769.565 & -3132.0183 \\
\hline-11.1456 & 0.023444695 & 2265.4744 down & -2265.474 & -2561.775 \\
\hline-9.776294 & 0.023451306 & 876.91534 down & -876.9153 & -990.9939 \\
\hline 11.925119 & 0.023500301 & 3888.8271 up & 3888.8271 & 3436.6948 \\
\hline-10.8379 & 0.023510749 & 1830.3417 down & -1830.342 & -2069.5393 \\
\hline 13.176004 & 0.02374818 & 9254.917 up & 9254.917 & 8180.2847 \\
\hline-13.03395 & 0.023875253 & 8387.067 down & -8387.067 & -194685.02 \\
\hline 11.992132 & 0.024171744 & 4073.7231 up & 4073.7231 & 3600.1392 \\
\hline-16.50515 & 0.024295963 & 93013.086 down & -93013.09 & -4895290.5 \\
\hline 0.6550426 & 0.024993513 & 1.5746624 up & 1.5746624 & 90883.89 \\
\hline-13.75823 & 0.025185674 & 13856.04 down & -13856.04 & -15673.383 \\
\hline-13.64294 & 0.025370691 & 12791.854 down & -12791.85 & -14469.542 \\
\hline-10.81263 & 0.02547326 & 1798.5686 down & -1798.569 & -2033.5967 \\
\hline-10.7536 & 0.025527824 & 1726.4564 down & -1726.456 & -1952.0211 \\
\hline-10.28215 & 0.025630502 & 1245.1852 down & -1245.185 & -1407.5922 \\
\hline-9.393279 & 0.025814945 & 672.44806 down & -672.4481 & -759.69415 \\
\hline-10.05848 & 0.025895737 & 1066.3583 down & -1066.358 & -12614.292 \\
\hline-10.70735 & 0.026203861 & 1671.9869 down & -1671.987 & -1890.4036 \\
\hline-9.846104 & 0.026781712 & 920.39136 down & -920.3914 & -1040.1747 \\
\hline-9.672007 & 0.026887886 & 815.7632 down & -815.7632 & -921.81604 \\
\hline-11.62794 & 0.02704956 & 3164.8997 down & -3164.9 & -3579.2327 \\
\hline-11.05239 & 0.02710642 & 2123.7324 down & -2123.732 & -2401.4321 \\
\hline-11.35168 & 0.027201256 & 2613.3342 down & -2613.334 & -2955.285 \\
\hline-10.72455 & 0.027357979 & 1692.0427 down & -1692.043 & -1913.0912 \\
\hline-10.03371 & 0.027414167 & 1048.206 down & -1048.206 & -1184.7633 \\
\hline-9.99965 & 0.027440438 & 1023.7516 down & -1023.752 & -1157.0996 \\
\hline
\end{tabular}




\begin{tabular}{rrrrr}
\hline-12.24901 & 0.027467487 & 4867.645 down & -4867.645 & -5505.431 \\
\hline-9.711211 & 0.027518565 & 838.23517 down & -838.2352 & -947.2376 \\
\hline-9.646583 & 0.027563078 & 801.51324 down & -801.5132 & -905.6967 \\
\hline-9.82249 & 0.027581975 & 905.4491 down & -905.4491 & -1023.2721 \\
\hline-10.17404 & 0.027652297 & 1155.2904 down & -1155.29 & -1305.8995 \\
\hline-9.259206 & 0.027745854 & 612.77167 down & -612.7717 & -692.18634 \\
\hline-9.401764 & 0.02791709 & 676.41455 down & -676.4146 & -764.18115 \\
\hline-9.855497 & 0.028441766 & 926.4038 down & -926.4038 & -11276.918 \\
\hline-11.05912 & 0.02904646 & 2133.6711 down & -2133.671 & -2412.675 \\
\hline-9.715218 & 0.02909249 & 840.56616 down & -840.5662 & -10110.91 \\
\hline 10.007375 & 0.031232027 & 1029.2479 up & 1029.2479 & 11227.518 \\
\hline
\end{tabular}




\begin{tabular}{|c|c|c|c|}
\hline Abund Diff (Log2) & Alignment Value & CompositeSpectrum & Mass \\
\hline-18.17869 & & $(391.28793,16340.016)(39 ;$ & 392.2951 \\
\hline 14.447212 & & $(718.599,1531.82)(719.598$ & 719.6055 \\
\hline 13.587301 & & $(810.5079,2796.5103)(811$. & 811.5144 \\
\hline 13.1000805 & & $(934.5643,3082.9175)(935$. & 935.5716 \\
\hline 16.013258 & & $(822.43915,24944.312)(82:$ & 823.4462 \\
\hline 15.211804 & & $(590.5232,13872.777)(591$. & 591.5298 \\
\hline 16.32327 & & $(572.52795,3386.4136)(57:$ & 537.5588 \\
\hline 17.898687 & & $(1506.1051,829.38)(1507.1$ & 753.5568 \\
\hline 23.182467 & & $(508.52103,3217930.2)(50 !$ & 509.528 \\
\hline 15.492642 & & $(794.4079,21526.156)(795$. & 795.4147 \\
\hline 16.249485 & & $(612.69684,14742.299)(61:$ & 613.7038 \\
\hline 14.913971 & & $(878.5015,12617.505)(879$. & 879.5086 \\
\hline 16.30963 & & $(618.5355,33105.984)(619$. & 619.5429 \\
\hline 13.305708 & & $(780.39325,4319.403)(781$. & 781.4012 \\
\hline 16.260786 & & $(625.70654,39599.11)(565$. & 566.6927 \\
\hline 15.234604 & & $(850.4705,23252.906)(851$. & 851.4783 \\
\hline 14.269907 & & $(239.23674,9783.122)(240$. & 240.2442 \\
\hline 15.507067 & & $(530.48047,2384.6938)(53:$ & 495.5118 \\
\hline 17.604147 & & $(626.7126,56446.402)(627$. & 567.6986 \\
\hline 15.682883 & & $(241.25255,38201.016)(24 i$ & 242.2597 \\
\hline 12.057058 & & $(797.39154,2415.7976)(79 ؛$ & 798.3992 \\
\hline 13.601585 & & $(808.4241,5783.6025)(809$. & 809.4308 \\
\hline 15.508161 & & $(566.4789,17863.572)(567$. & 567.4859 \\
\hline 13.804244 & & $(906.5325,6764.4165)(907$. & 907.5388 \\
\hline 15.422135 & & $(646.55444,7079.896)(647$. & 647.5615 \\
\hline 18.447302 & & $(632.55176,175174.78)(63:$ & 633.5588 \\
\hline 14.843368 & & $(516.46387,1563.6362)(51:$ & 481.4959 \\
\hline 13.090727 & & $(941.78296,1573.7474)(94 i$ & 942.7914 \\
\hline 13.994268 & & $(644.4874,3041.311)(645.4$ & 645.4982 \\
\hline 12.692832 & & $(828.7652,668.44336)(792$. & 793.794 \\
\hline 15.002667 & & $(766.37646,20441.887)(76$ & 767.3841 \\
\hline 13.887589 & & $(633.50665,4146.995)(634$. & 634.5134 \\
\hline 11.725124 & & $(881.48376,2462.3774)(88:$ & 882.4914 \\
\hline 12.835672 & & $(706.7037,1332.3586)(707$. & 707.7108 \\
\hline 15.316587 & & $(241.25273,23733.406)(24 i$ & 242.2601 \\
\hline 12.531479 & & $(724.3304,2730.2988)(725$. & 725.3374 \\
\hline 13.121777 & & $(571.4953,1846.8639)(572$. & 572.5035 \\
\hline 14.549034 & & $(738.34503,16817.006)(73 !$ & 739.353 \\
\hline 12.176996 & & $(505.4963,2496.0798)(506$. & 506.5045 \\
\hline 12.913131 & & $(752.3635,3525.7524)(753$. & 753.3713 \\
\hline 17.505491 & & $(507.51434,103130.016)(5)$ & 508.5217 \\
\hline 14.898531 & & $(604.50793,12258.867)(60 !$ & 605.5148 \\
\hline 13.924147 & & $(672.5281,1429.4241)(673$. & 673.5342 \\
\hline 13.418156 & & $(642.4071,1130.4719)(643$. & 643.4132 \\
\hline 13.993773 & & $(895.7905,1124.36)(896.79$ & 896.7988 \\
\hline 14.001427 & & $(688.60046,1276.5979)(68 !$ & 689.6095 \\
\hline
\end{tabular}




\begin{tabular}{|c|c|c|}
\hline 13.242032 & $(835.7707,1240.078)(836.7$ & 836.7786 \\
\hline 13.717704 & $(696.29913,1793.282)(697$. & 697.3067 \\
\hline 12.950745 & $(807.74304,1337.112)(808$. & 808.7509 \\
\hline 13.782116 & $(710.31464,9881.722)(711$. & 711.3218 \\
\hline 12.423693 & $(477.5027,4488.695)(478.5$ & 478.5098 \\
\hline 13.397118 & $(653.5351,2806.3076)(654$. & 654.543 \\
\hline-14.113853 & $(1097.7836,1215.135)(109)$ & 1098.7911 \\
\hline 14.528566 & $(1097.784,1234.1)(1098.78$ & 1062.8143 \\
\hline 13.601116 & $(1024.0537,1503.7175)(10$ & 1025.0608 \\
\hline 21.169533 & $(1018.0504,659275.6)(101 !$ & 1019.0572 \\
\hline 15.1130495 & $(1001.8049,6280.0474)(10($ & 1002.8115 \\
\hline 15.446462 & $(629.6913,9935.298)(630.6$ & 630.6986 \\
\hline 15.190352 & $(1040.0297,9468.508)(104:$ & 1041.0367 \\
\hline 13.020963 & $(1097.988,1728.0325)(109 ؛$ & 1098.9963 \\
\hline 14.57087 & $(539.50287,3018.9)(540.50$ & 240.2442 \\
\hline 13.7709255 & $(882.84125,3709.8975)(88:$ & 883.8483 \\
\hline 16.817593 & $(551.5037,38803.242)(552$. & 552.5111 \\
\hline-12.471074 & $(614.499,5810.3325)(615.5$ & 615.5059 \\
\hline-10.941644 & $(940.6085,1336.3586)(941$. & 941.6179 \\
\hline 13.098574 & $(883.7776,2406.0776)(884$. & 884.7848 \\
\hline 13.219475 & $(653.49304,1734.1824)(65$ & 654.5008 \\
\hline 13.411222 & $(726.67365,2492.6763)(72$ & 727.6817 \\
\hline 12.512407 & $(451.45023,2503.5837)(45:$ & 452.4582 \\
\hline-11.285672 & $(287.10825,3992.33)(288.1$ & 288.1173 \\
\hline-15.1770115 & $(290.90497,1856.1719)(29$ : & 291.9122 \\
\hline-17.198414 & $(551.5038,14632.885)(552$. & 552.5111 \\
\hline-12.133701 & $(1055.7761,4075.3577)(10 !$ & 1056.7855 \\
\hline-11.018249 & $(437.27725,2324.3533)(43 i$ & 438.2848 \\
\hline 11.375064 & $(343.2338,2480.7869)(344$. & 344.241 \\
\hline 10.058337 & $(619.491,1232.52)(620.494$ & 620.4974 \\
\hline 10.604065 & $(683.5102,1545.8534)(684$. & 684.5189 \\
\hline 11.1824875 & $(1155.0586,910.93)(1156.0$ & 548.0226 \\
\hline 11.740564 & $(571.8481,4850.8633)(572$. & 572.8572 \\
\hline 11.431657 & $(1020.5393,8242.671)(102:$ & 1021.5525 \\
\hline 9.442136 & $(763.7514,1161.9767)(764$. & 764.7597 \\
\hline 10.910389 & $(862.6285,1210.7667)(863$. & 863.6365 \\
\hline 10.430017 & $(419.3043,1839.3734)(420$. & 420.3119 \\
\hline 10.622065 & $(630.20734,1992.7032)(63:$ & 631.2144 \\
\hline 9.739268 & $(592.6136,1429.5533)(593$. & 593.6203 \\
\hline 11.772378 & $(713.47363,3146.8)(714.47$ & 714.4809 \\
\hline 9.671286 & $(607.5079,1100.9033)(608$. & 608.515 \\
\hline 11.116716 & $(511.87186,5200.0034)(51 i$ & 512.8693 \\
\hline 13.122294 & $(558.50836,637.3825)(522$. & 523.5431 \\
\hline 11.43243 & $(789.61395,2211.6833)(79)$ & 790.6112 \\
\hline 12.012771 & $(794.5481,2814.3232)(795$. & 795.5545 \\
\hline 12.233984 & $(828.71106,1346.6113)(82 !$ & 829.7179 \\
\hline 12.7368555 & $(684.4637,561.22)(624.438$ & 625.4464 \\
\hline
\end{tabular}




\begin{tabular}{|c|c|c|}
\hline 12.504948 & $(825.4205,3925.859)(826.4$ & 826.4281 \\
\hline 9.149434 & $(780.4028,1992.63)(781.40$ & 781.4095 \\
\hline 11.989852 & $(853.45386,2693.4448)(85$ & 854.4591 \\
\hline-14.821398 & $(665.49664,6485.576)(666$. & 666.5035 \\
\hline 13.57152 & $(733.5816,1921.435)(734.5$ & 734.5882 \\
\hline 15.638477 & $(593.5418,7903.3667)(594$. & 594.5491 \\
\hline 14.805527 & $(754.58185,1383.6599)(75 !$ & 753.5745 \\
\hline 15.194512 & $(796.5645,4072.4297)(797$. & 795.5572 \\
\hline-14.056743 & $(832.6198,1425.1741)(833$. & 831.6166 \\
\hline-16.581503 & $(361.33246,4904.488)(362$. & 360.324 \\
\hline-14.35105 & $(610.54645,1930.6439)(61:$ & 609.5384 \\
\hline-13.29329 & $(978.84296,1174.462)(979$. & 977.8417 \\
\hline-19.53423 & $(857.84143,217741.38)(85 i$ & 856.8291 \\
\hline 16.336649 & $(361.33105,3878.5122)(36 ;$ & 360.3239 \\
\hline 13.777534 & $(723.50836,1462.154)(724$. & 722.504 \\
\hline 10.000782 & $(309.23477,1623.8033)(311$ & 308.2274 \\
\hline 10.469365 & $(593.41815,1242.6666)(27 i$ & 277.227 \\
\hline 10.552937 & $(529.4046,1231.0533)(530$. & 528.3982 \\
\hline 10.627539 & $(775.57355,1948.1401)(771$ & 774.5694 \\
\hline 11.4587 & $(586.44366,4390.143)(587$. & 585.4367 \\
\hline-10.253861 & $(319.21637,2610.42)(320.2$ & 318.2104 \\
\hline-11.612877 & $(589.4659,3053.6165)(590$. & 588.4565 \\
\hline-11.322928 & $(543.40155,2875.8867)(54$ & 542.3964 \\
\hline-9.952732 & $(920.75507,1103.2533)(92:$ & 919.7473 \\
\hline 11.746806 & $(594.4964,2140.8533)(595$. & 593.4894 \\
\hline-11.015094 & $(603.40936,2243.79)(604.4$ & 602.4018 \\
\hline 12.997935 & $(560.4333,11388.434)(561$. & 559.4262 \\
\hline-17.570782 & $(368.3729,17773.307)(369$. & 367.3628 \\
\hline 11.813837 & $(728.58057,9520.267)(729$. & 727.5683 \\
\hline-22.222963 & $(186.22197,764228.3)(187$. & 185.2139 \\
\hline 16.471737 & $(202.21822,28594.693)(20$ & 201.2113 \\
\hline-13.936029 & $(447.35025,57065.88)(448$. & 446.3449 \\
\hline-13.820731 & $(447.35165,51714.34)(448$. & 446.3443 \\
\hline-10.989818 & $(872.7524,1225.89)(873.74$ & 871.7458 \\
\hline-10.930753 & $(433.33972,5398.5864)(43 ،$ & 432.3353 \\
\hline-10.459014 & $(508.5825,1118.8967)(509$. & 507.5766 \\
\hline-9.569275 & $(1697.6527,1057.42)(1698$. & 1696.6396 \\
\hline-13.622771 & $(904.80566,1509.876)(905$. & 903.8038 \\
\hline-10.884479 & $(816.66455,1432.4332)(81:$ & 815.6512 \\
\hline-10.02261 & $(1011.699,1115.6266)(101 i$ & 1010.6949 \\
\hline-9.848335 & $(958.70294,1139.0967)(95 !$ & 957.6896 \\
\hline-11.805434 & $(261.15457,7756.563)(262$. & 260.1458 \\
\hline-11.229679 & $(682.55176,2029.85)(683.5$ & 681.5471 \\
\hline-11.529081 & $(453.3689,2153.96)(454.37$ & 452.3585 \\
\hline-10.90169 & $(815.6065,1696.3932)(816$. & 814.602 \\
\hline-10.210383 & $(759.69855,2154.3767)(76)$ & 758.6929 \\
\hline-10.176297 & $(1042.7837,1190.0366)(10$ & 1041.7758 \\
\hline
\end{tabular}




\begin{tabular}{rlr}
\hline-12.42664 & $(731.612,7137.719)(732.61$ & 730.6056 \\
\hline-9.887583 & $(863.7835,1236.44)(864.77$ & 862.7744 \\
\hline-9.822885 & $(570.5477,1313.0834)(571$. & 569.5366 \\
\hline-9.998974 & $(389.25525,1727.9434)(391$ & 388.247 \\
\hline-10.350828 & $(849.6731,2230.5198)(850$. & 848.6615 \\
\hline-9.435017 & $(750.32007,1152.0599)(75:$ & 749.3153 \\
\hline-9.577771 & $(896.861,1097.23)(897.848$ & 895.8587 \\
\hline-13.461085 & $(820.7433,1326.2161)(821$. & 819.7402 \\
\hline-11.236418 & $(814.68915,5866.6626)(81 !$ & 813.6815 \\
\hline-13.303625 & $(794.7292,1428.0519)(795$. & 793.7219 \\
\hline 13.454751 & $(765.63916,1181.9099)(761$ & 764.6341 \\
\hline
\end{tabular}




\begin{tabular}{|c|c|c|c|}
\hline Retention Time & KEGG ID & LMP ID & Ionization \\
\hline 10.1814995 & & & - \\
\hline 9.690249 & & LMGP02040002 & - \\
\hline 6.69825 & & LMGP02010961 & - \\
\hline 10.32 & & & - \\
\hline 9.345625 & C15732 & & - \\
\hline 9.67875 & & & - \\
\hline 9.947374 & & & - \\
\hline 6.6997495 & & LMGP02010329 & - \\
\hline 9.689125 & & & - \\
\hline 9.01925 & C15705 & & - \\
\hline 7.652 & & & - \\
\hline 9.887375 & & LMGP01030017 & - \\
\hline 8.5130005 & C18138 & & - \\
\hline 9.0195 & & & - \\
\hline 7.6509995 & & & - \\
\hline 9.62225 & C15729 & & - \\
\hline 10.410376 & HMDB0155: C00517 & LMFA06000088 & - \\
\hline 9.529125 & & & - \\
\hline 7.6485 & & & - \\
\hline 10.410126 & & LMFA05000010 & - \\
\hline 9.020625 & & & - \\
\hline 9.34525 & C15704 & & - \\
\hline 9.679249 & & & - \\
\hline 10.119625 & C05306 & & - \\
\hline 9.68425 & & & - \\
\hline 8.513376 & & & - \\
\hline 9.373624 & & & - \\
\hline 10.436375 & & & - \\
\hline 9.685876 & & LMGP02020039 & - \\
\hline 10.519501 & & & - \\
\hline 8.648625 & C03796 & & - \\
\hline 7.8888755 & & LMGL02010196 & - \\
\hline 9.886624 & & LMST01080090 & - \\
\hline 7.659375 & C15244 & & - \\
\hline 7.887875 & & LMFA05000010 & - \\
\hline 8.226375 & & & - \\
\hline 7.9888754 & & & - \\
\hline 8.226999 & & & - \\
\hline 7.8872504 & & LMFA01020322 & - \\
\hline 8.647875 & & & - \\
\hline 7.88775 & & LMFA01020318 & - \\
\hline 9.677375 & & & - \\
\hline 9.6826 & & LMGP02020102 & - \\
\hline 9.6798 & C16998 & & - \\
\hline 5.2937994 & C14438 & & - \\
\hline 9.6846 & & & - \\
\hline
\end{tabular}




\begin{tabular}{|c|c|c|c|}
\hline 10.0204 & C15798 & & - \\
\hline 7.7398005 & C12044 & LMPK05000005 & - \\
\hline 10.408999 & & LMST01010135 & - \\
\hline 7.7454996 & C19247 & & - \\
\hline 10.409625 & & & - \\
\hline 8.578875 & C05811 & & - \\
\hline 10.771501 & & & - \\
\hline 10.766999 & & & - \\
\hline 9.682 & & & - \\
\hline 9.681625 & & & - \\
\hline 10.81375 & & LMGL03012585 & - \\
\hline 7.64125 & & LMFA05000036 & - \\
\hline 9.677375 & & LMFA07010023 & - \\
\hline 9.676624 & & LMST03020221 & - \\
\hline 7.8883758 & C00517 & LMFA06000088 & - \\
\hline 9.727125 & & & - \\
\hline 6.345625 & & & - \\
\hline 7.889375 & & & - \\
\hline 6.7009997 & & & - \\
\hline 7.889125 & & LMGL03010272 & - \\
\hline 8.306749 & & LMGP10030037 & - \\
\hline 7.6369996 & C18965 & & - \\
\hline 9.174375 & & LMFA01020314 & - \\
\hline 5.211 & C11769 & & - \\
\hline 5.2922 & & & - \\
\hline 6.2144 & & & - \\
\hline 10.81925 & & LMFA01170127 & - \\
\hline 3.9363334 & & LMFA01050016 & - \\
\hline 5.32 & & LMFA03010086 & - \\
\hline 7.8863335 & C14308 & & - \\
\hline 9.488667 & & LMFA01060043 & - \\
\hline 9.683 & & & - \\
\hline 5.3103333 & C18779 & & - \\
\hline 9.689 & C18059 & & - \\
\hline 10.410666 & & LMFA01020350 & - \\
\hline 7.704666 & & LMSP0501AB14 & - \\
\hline 9.8186655 & & LMST03020391 & - \\
\hline 6.5606666 & & & - \\
\hline 10.400001 & C19224 & & - \\
\hline 7.9236665 & & LMGP04010195 & - \\
\hline 9.676999 & & & - \\
\hline 9.702 & C11040 & & - \\
\hline 9.811251 & & & - \\
\hline 7.778667 & & LMST01150011 & - \\
\hline 7.926 & C11698 & & - \\
\hline 7.69975 & C01060 & & - \\
\hline 9.6797495 & & & - \\
\hline
\end{tabular}




\begin{tabular}{|c|c|c|c|}
\hline 9.345 & & & - \\
\hline 8.859125 & C14059 & & - \\
\hline 9.620875 & C17042 & & - \\
\hline 7.8868756 & & LMGP10020031 & - \\
\hline 9.444 & C15013 & & - \\
\hline 5.29775 & $\mathrm{C} 07036$ & & - \\
\hline 6.1599994 & & & + \\
\hline 8.234601 & & LMGP06020042 & + \\
\hline 8.1264 & & LMGP03010245 & + \\
\hline 4.4812 & & & + \\
\hline 8.2306 & & LMGL02010022 & + \\
\hline 10.4326 & & LMGL03011675 & + \\
\hline 10.624375 & & LMGL03010013 & + \\
\hline 4.3891997 & & & + \\
\hline 6.3623996 & & LMGP10030023 & + \\
\hline 10.086333 & C15033 & & + \\
\hline 0.92333335 & & & + \\
\hline 4.147333 & . 13425 & & + \\
\hline 8.155 & & & + \\
\hline 0.9253333 & C16505 & & + \\
\hline 10.634 & C06998 & & + \\
\hline \multicolumn{2}{|c|}{6.696333 HMDB07153 } & & + \\
\hline \multicolumn{2}{|c|}{0.928 HMDB0192( D00848 } & & + \\
\hline 10.632333 & & LMGP02010202 & + \\
\hline 4.1056666 & & LMGL02010311 & + \\
\hline 0.91899997 & & & + \\
\hline 11.537999 & C07881 & & + \\
\hline 5.0903997 & & & + \\
\hline 8.087001 & & LMGP02020053 & + \\
\hline 0.8116 & C02277 & LMFA05000001 & + \\
\hline 0.8846251 & & LMFA05000154 & + \\
\hline 10.760333 & & & + \\
\hline 10.505 & & & + \\
\hline 6.845 & & LMGL03010012 & + \\
\hline 11.319333 & & & + \\
\hline 10.271 & C14708 & & + \\
\hline 10.622334 & & & + \\
\hline 10.643 & & & + \\
\hline 5.2023335 & C01190 & & + \\
\hline 8.436667 & & LMST03020495 & + \\
\hline 9.744334 & C04150 & & + \\
\hline 4.858667 & & & + \\
\hline 4.712667 & $\mathrm{C} 05813$ & & + \\
\hline 5.237 & & & + \\
\hline 8.137666 & C16248 & & + \\
\hline 9.497333 & & & + \\
\hline 4.7036667 & & & + \\
\hline
\end{tabular}




\begin{tabular}{|clc|}
\hline 7.904 & C10385 & \\
\hline 10.317334 & LMFA01020362 & + \\
\hline 6.331 & LMSP02020019 & + \\
\hline 10.967 & & + \\
\hline 8.302001 & LMGL03010037 & + \\
\hline 7.682667 & LMPK12140071 & + \\
\hline 10.836334 & & + \\
\hline 10.134199 & LMGL03010018 & + \\
\hline 8.735333 & LMSP0501AA23 & + \\
\hline 10.106199 HMDB10412 & & + \\
\hline 8.7364 & LMFA01020037 & + \\
\hline
\end{tabular}

